\title{
Modular and Stereodivergent Approach to Unbranched 1,5,9,n-Polyenes: Total Synthesis of Chatenaytrienin-4
}

\author{
Juliane Adrian and Christian B. W. Stark* \\ Fachbereich Chemie, Institut für Organische Chemie, Universität Hamburg, \\ Martin-Luther-King-Platz 6, 20146 Hamburg, Germany \\ stark@chemie.uni-hamburg.de
}

\section{Supporting Information}

Pentadec-1-en-4-yne (16)

1-2

Pentadec-4-yn-1-ol (17)

3-4

(Z)-Pentadec-4-en-1-ol (18a)

5-6

(E)-Pentadec-4-en-1-ol (18b)

7-8

(Z)-Pentadec-4-enal (19a)

9-10

(E)-Pentadec-4-enal (19b)

11-12

(Z)-1,1-Dibromohexadeca-1,5-diene (20a)

13-14

(E)-1,1-Dibromohexadeca-1,5-diene (20b)

15-16

(Z)-Nonadeca-1,8-dien-4-yne (21a)

17-18

(E)-Nonadeca-1,8-dien-4-yne (21b)

19-20

(Z)-Nonadec-8-en-4-yn-1-ol (22a)

21-22

(E)-Nonadec-8-en-4-yn-1-ol (22b)

(4Z,8Z)-Nonadeca-4,8-dien-1-ol (23a)

(4E,8Z)-Nonadeca-4,8-dien-1-ol (23b)

27-28

(4Z,8E)-Nonadeca-4,8-dien-1-ol (23c)

29-30

(4E,8E)-Nonadeca-4,8-dien-1-ol (23d)

31-32

Pentadec-4-ynal (31)

1,1-Dibromohexadec-1-en-5-yne (32)

35-36

Hexadeca-1,5-diyne (34) 
(S,Z)-4-(Dotriaconta-13-en-17,21-diyn-1-yl)-2-methyl-5-oxo-2,5-dihydrofuran-3-yl trifluoromethanesulfonate (39)

(S)-4-((13Z,17Z,21Z)-Dotriaconta-13,17,21-trien-1-yl)-2-methyl-5-oxo-2,5-dihydrofuran-3-yl trifluoromethanesulfonate $\mathbf{( 4 0 )}$ 


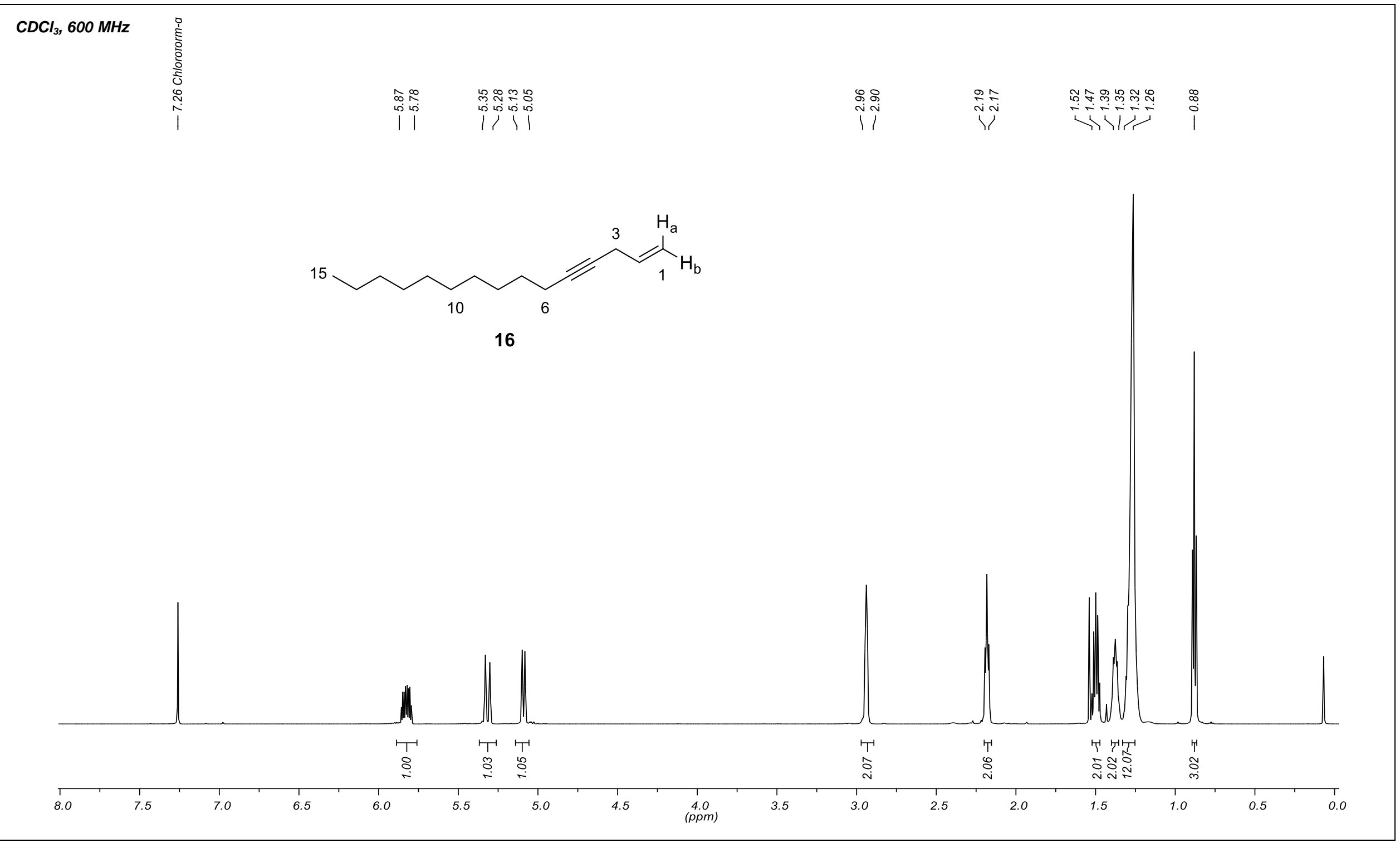




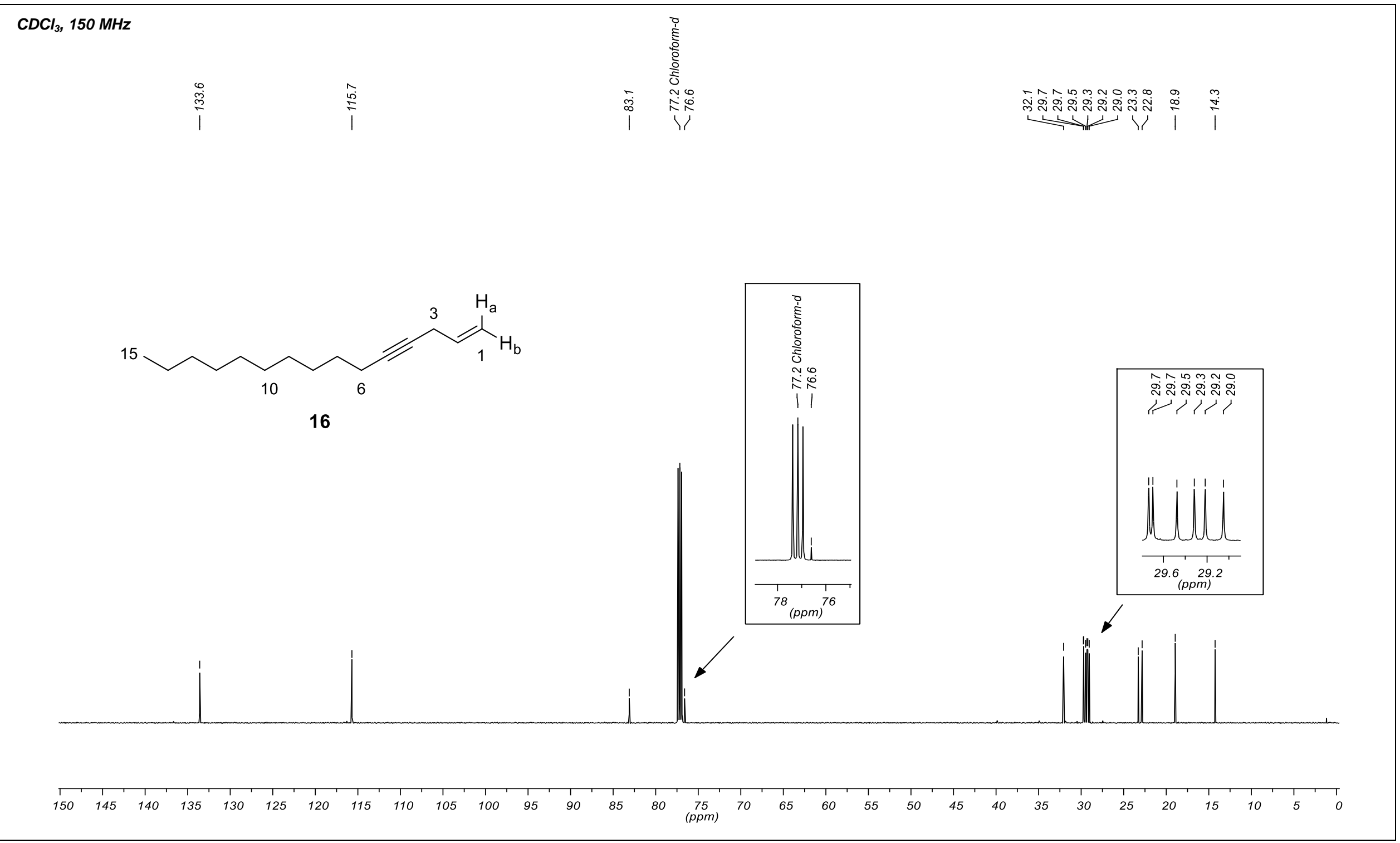




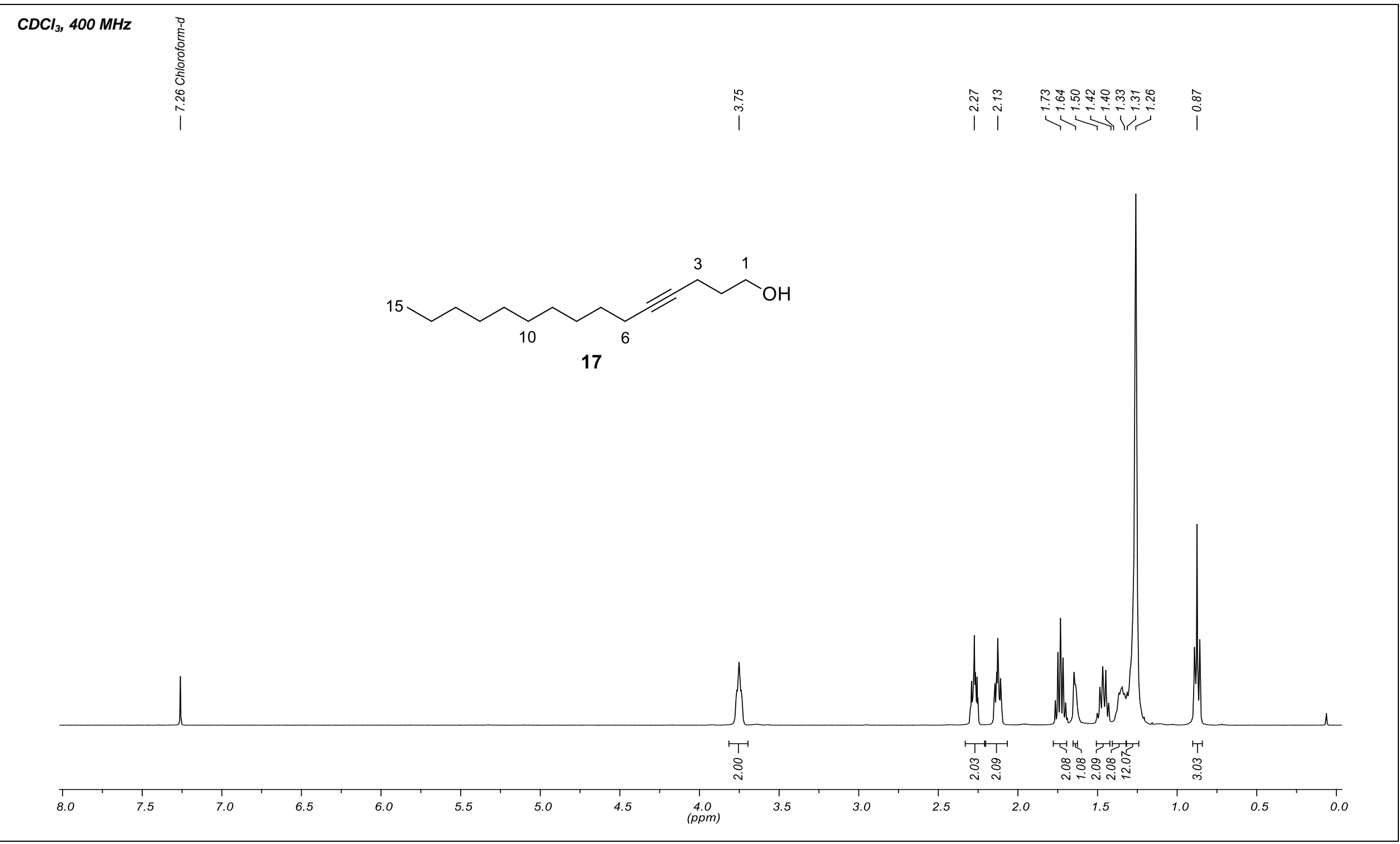



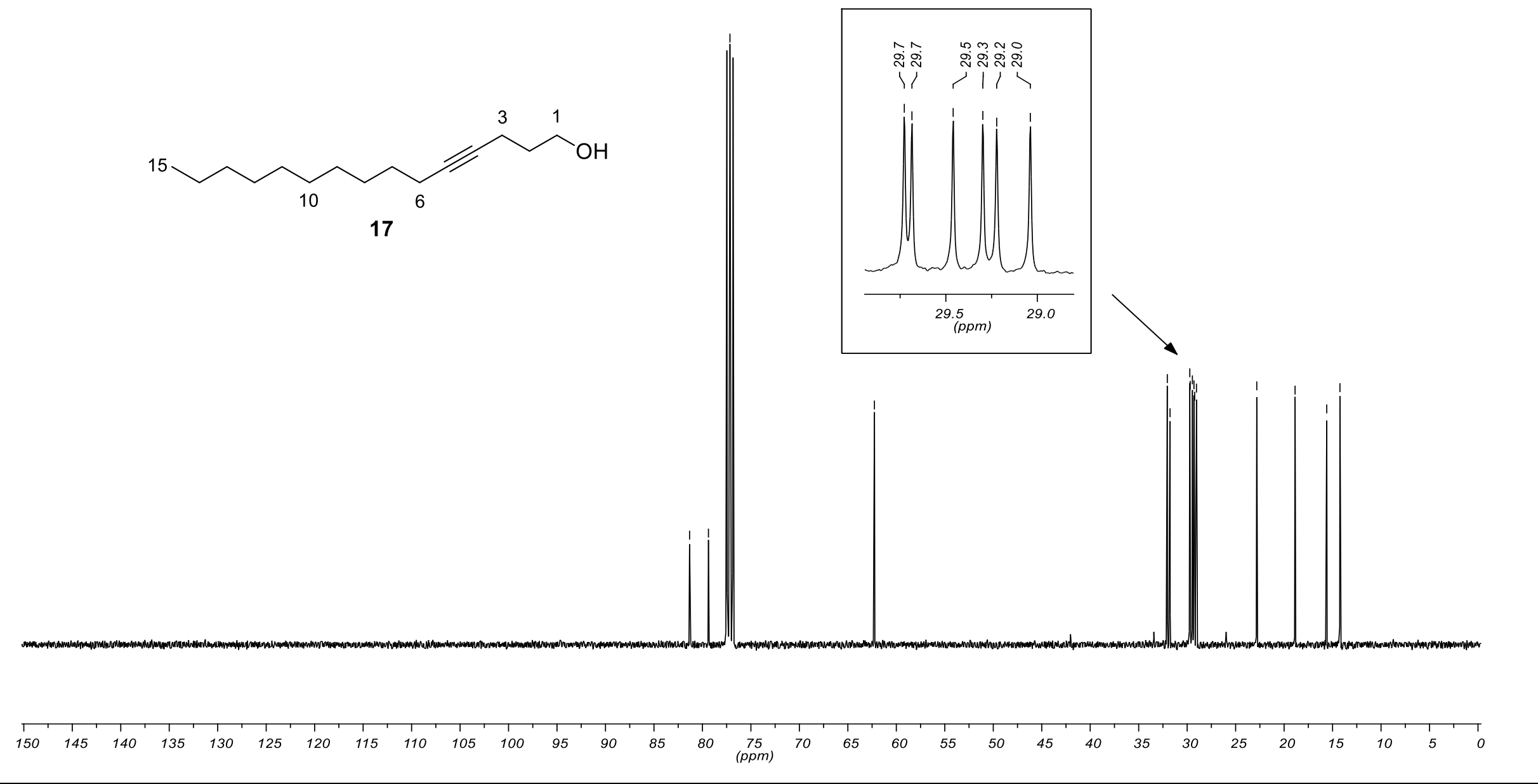


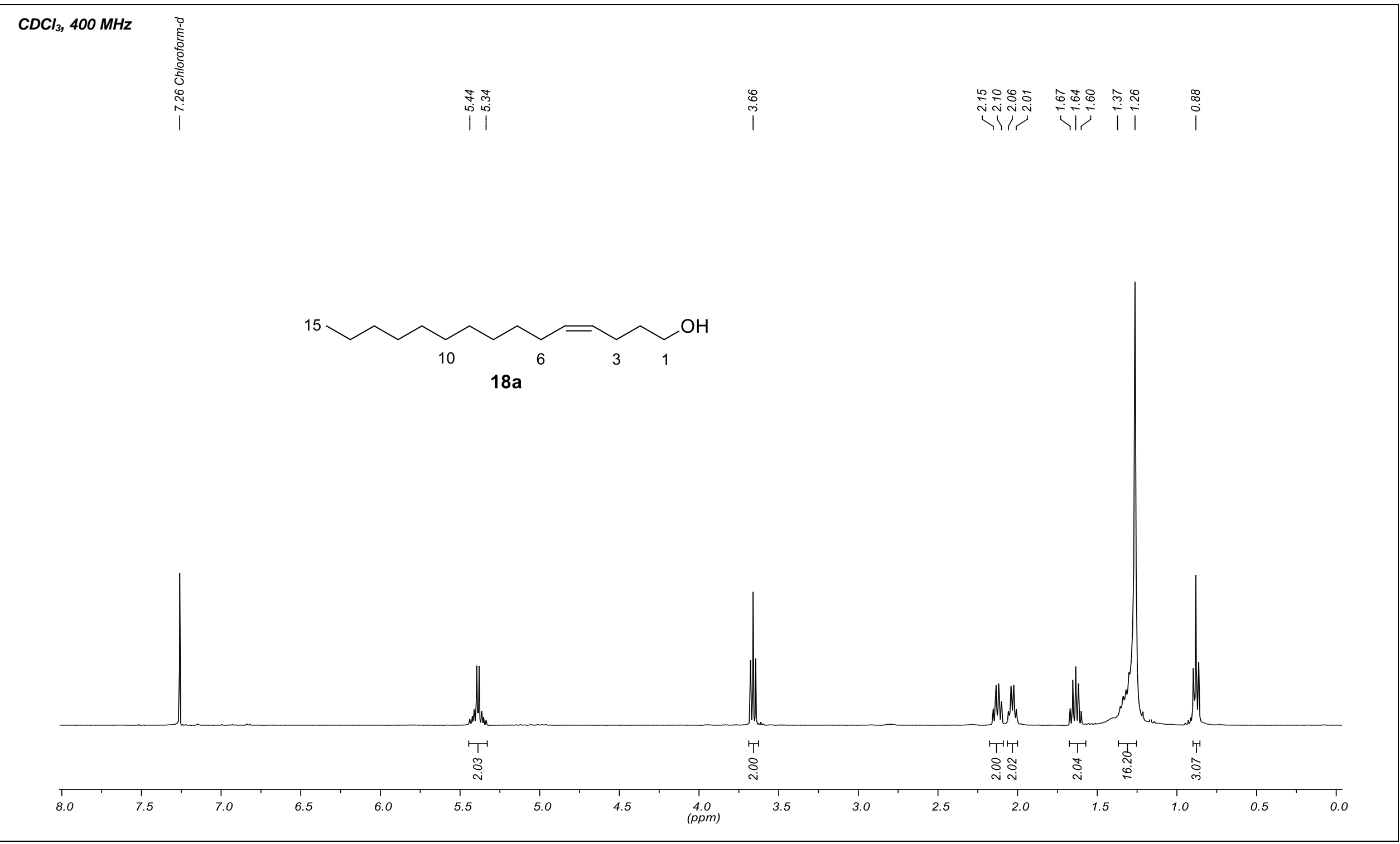




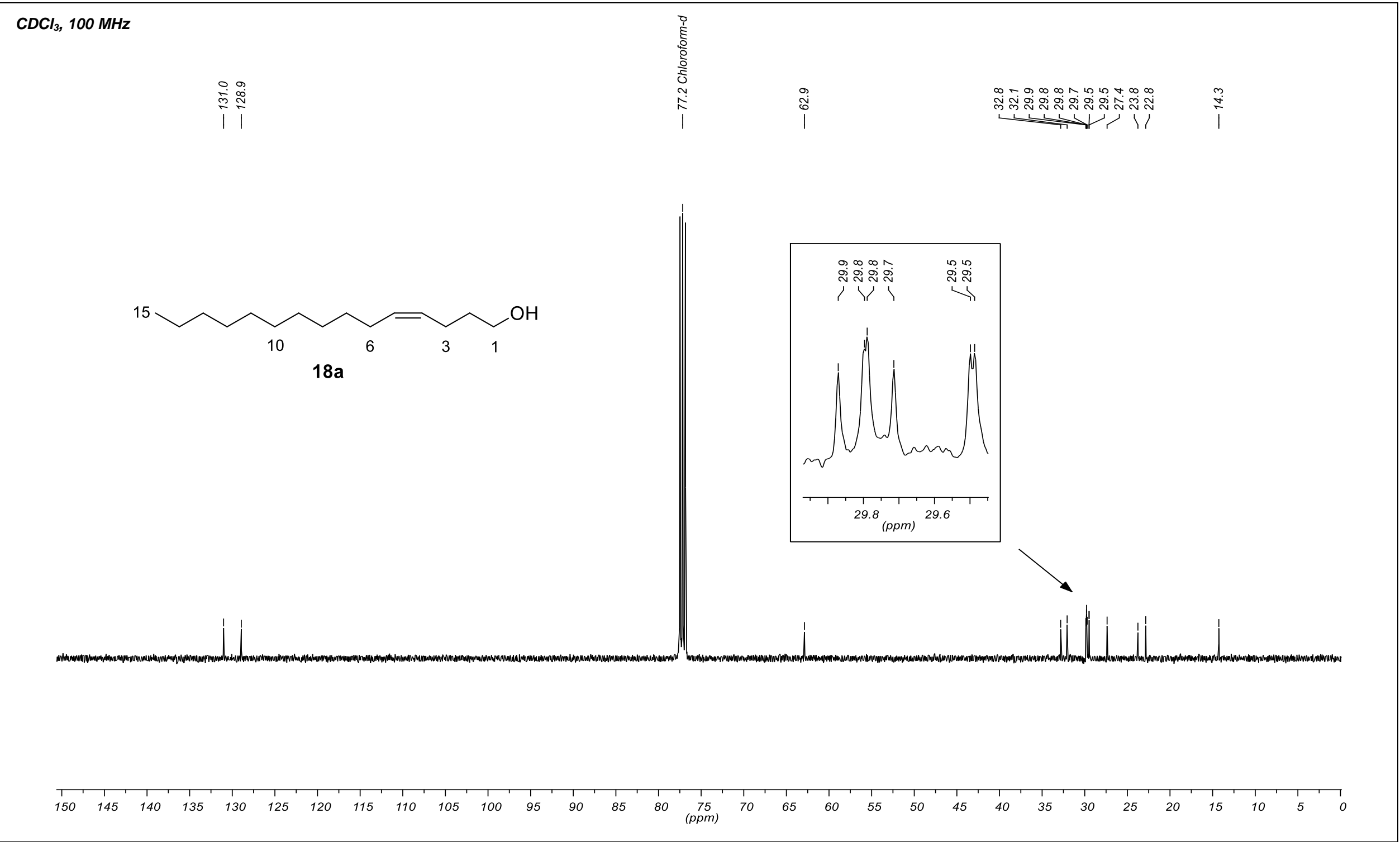




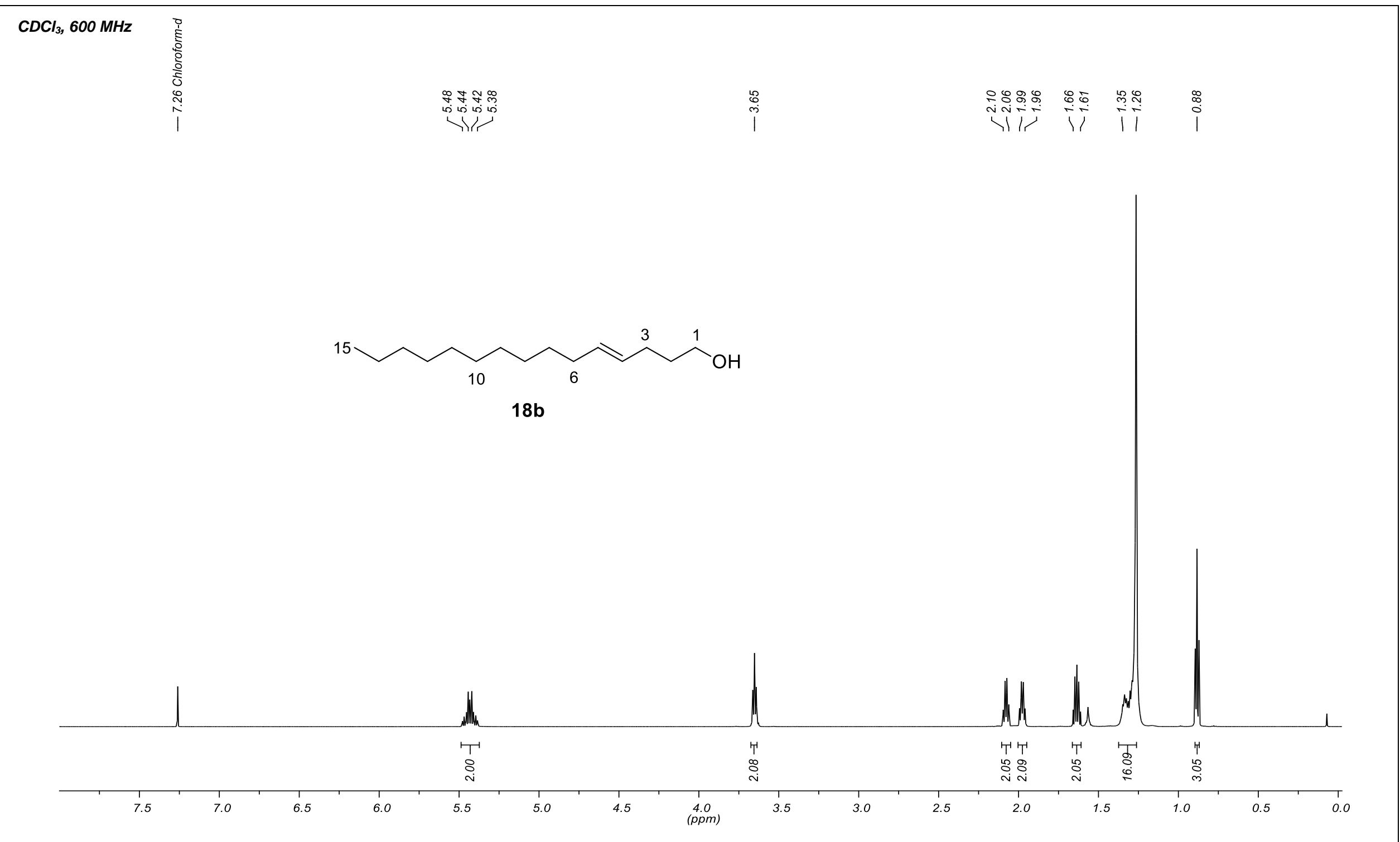




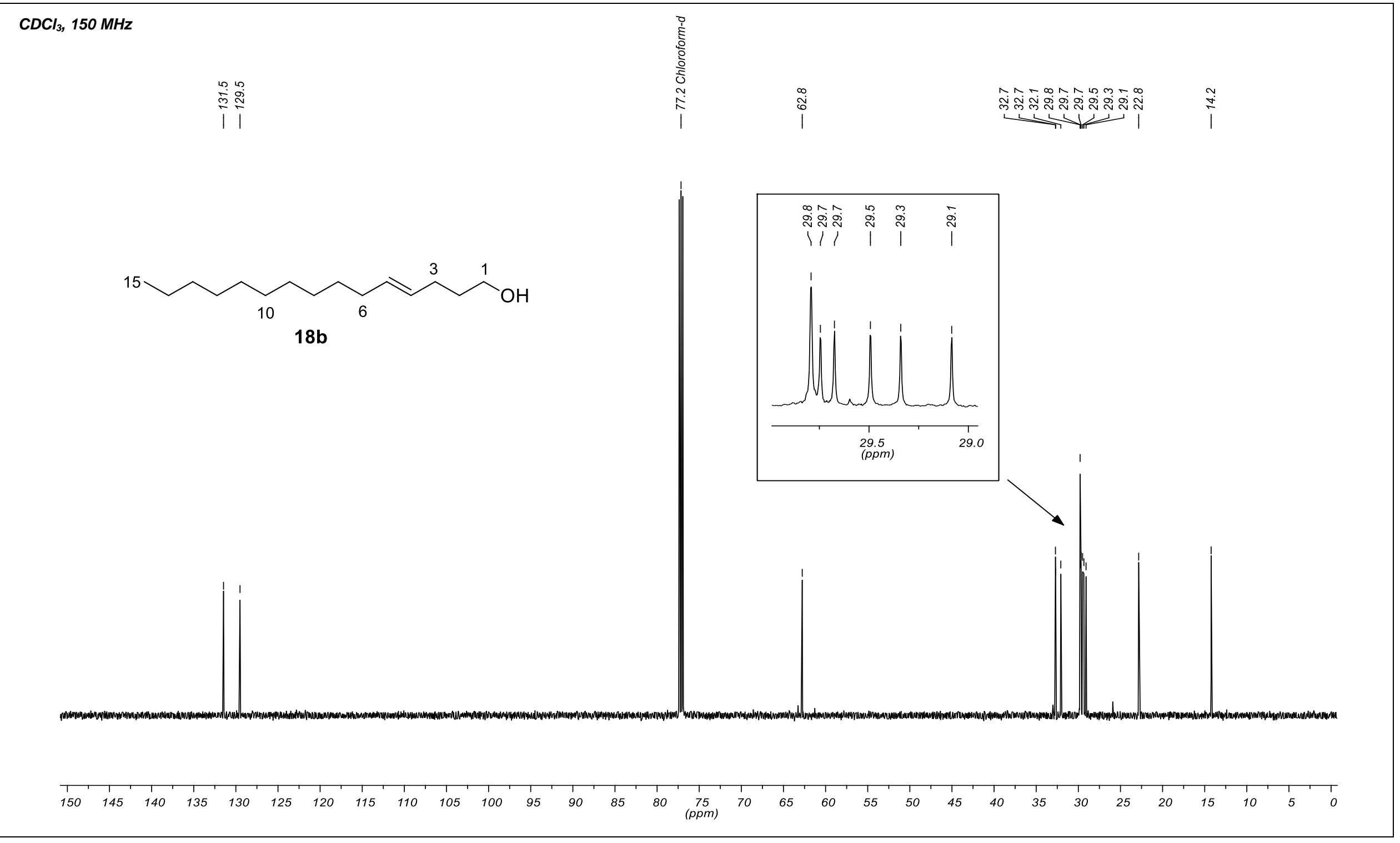




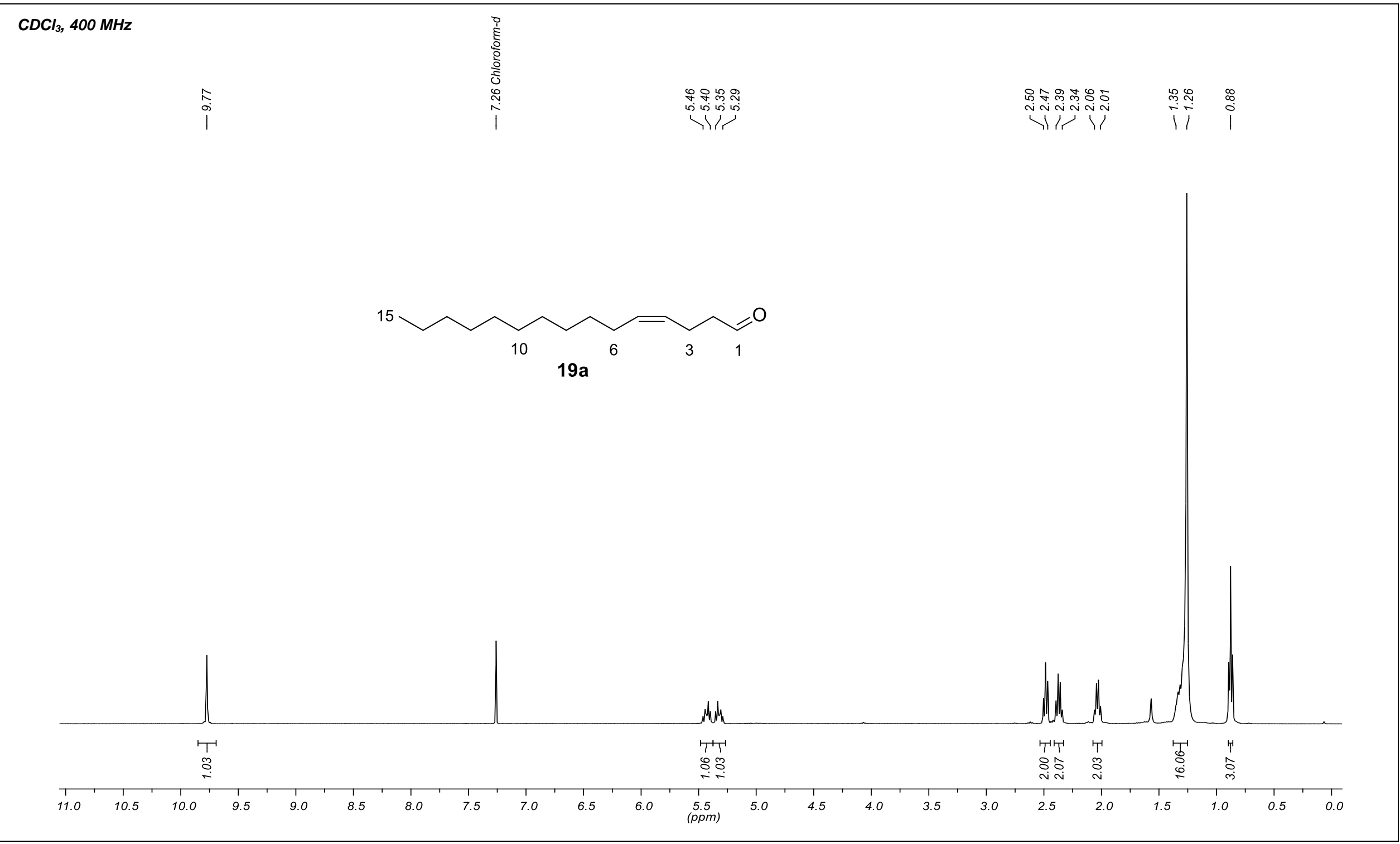


$\mathrm{CDCl}_{3}, 100 \mathrm{MH}$

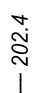

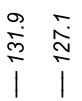

造

।

15

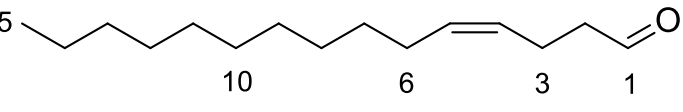

$19 a$

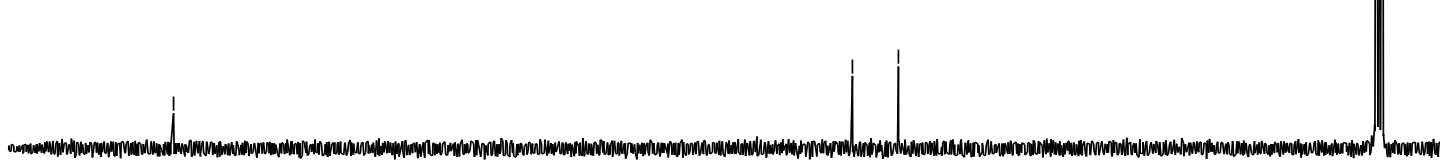

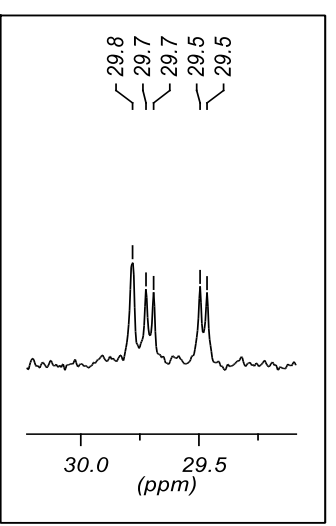

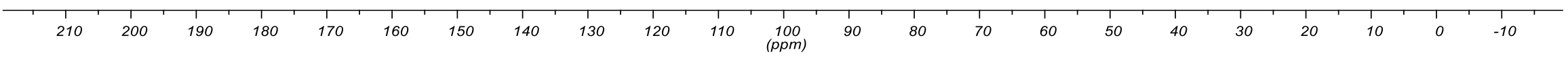




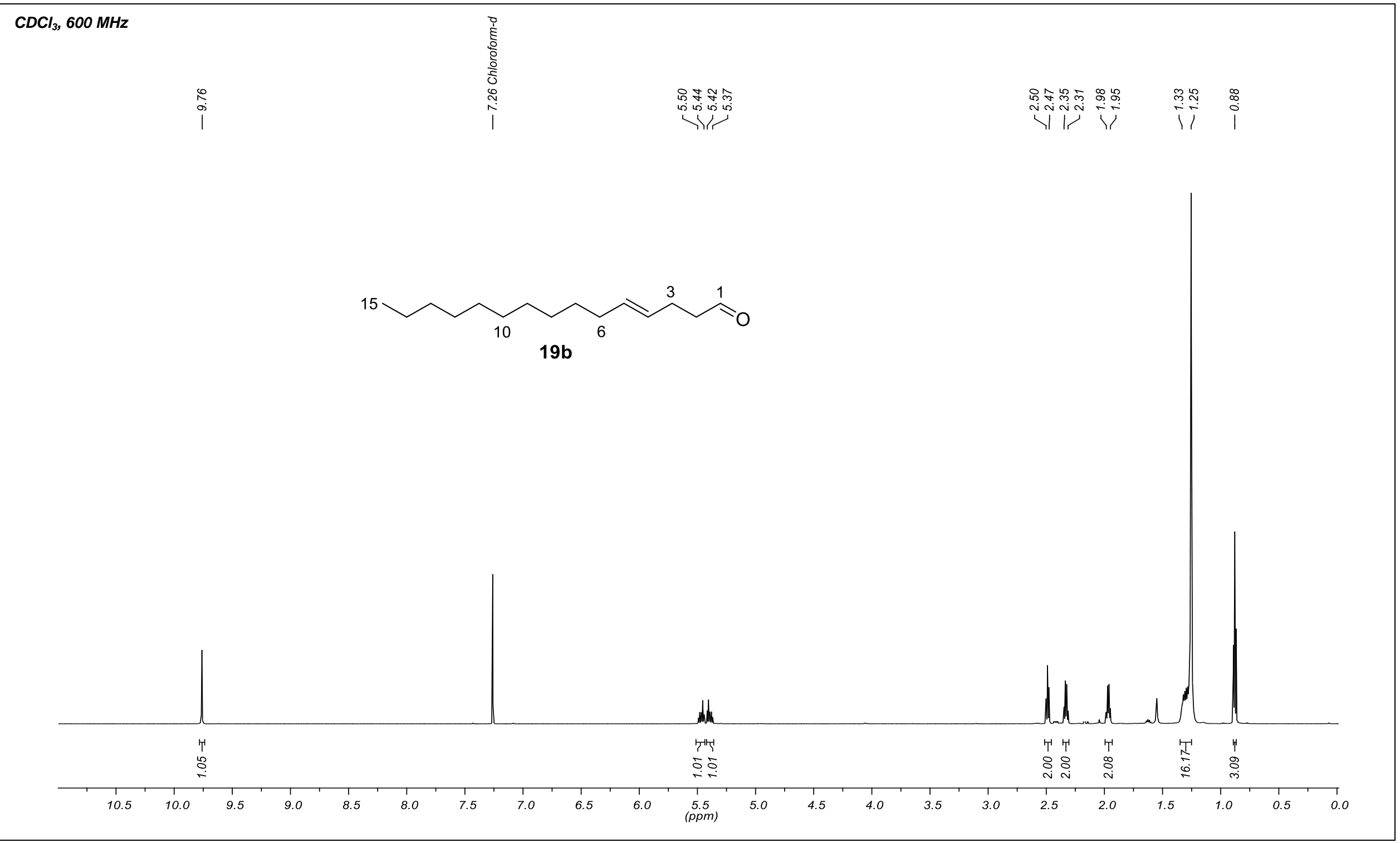




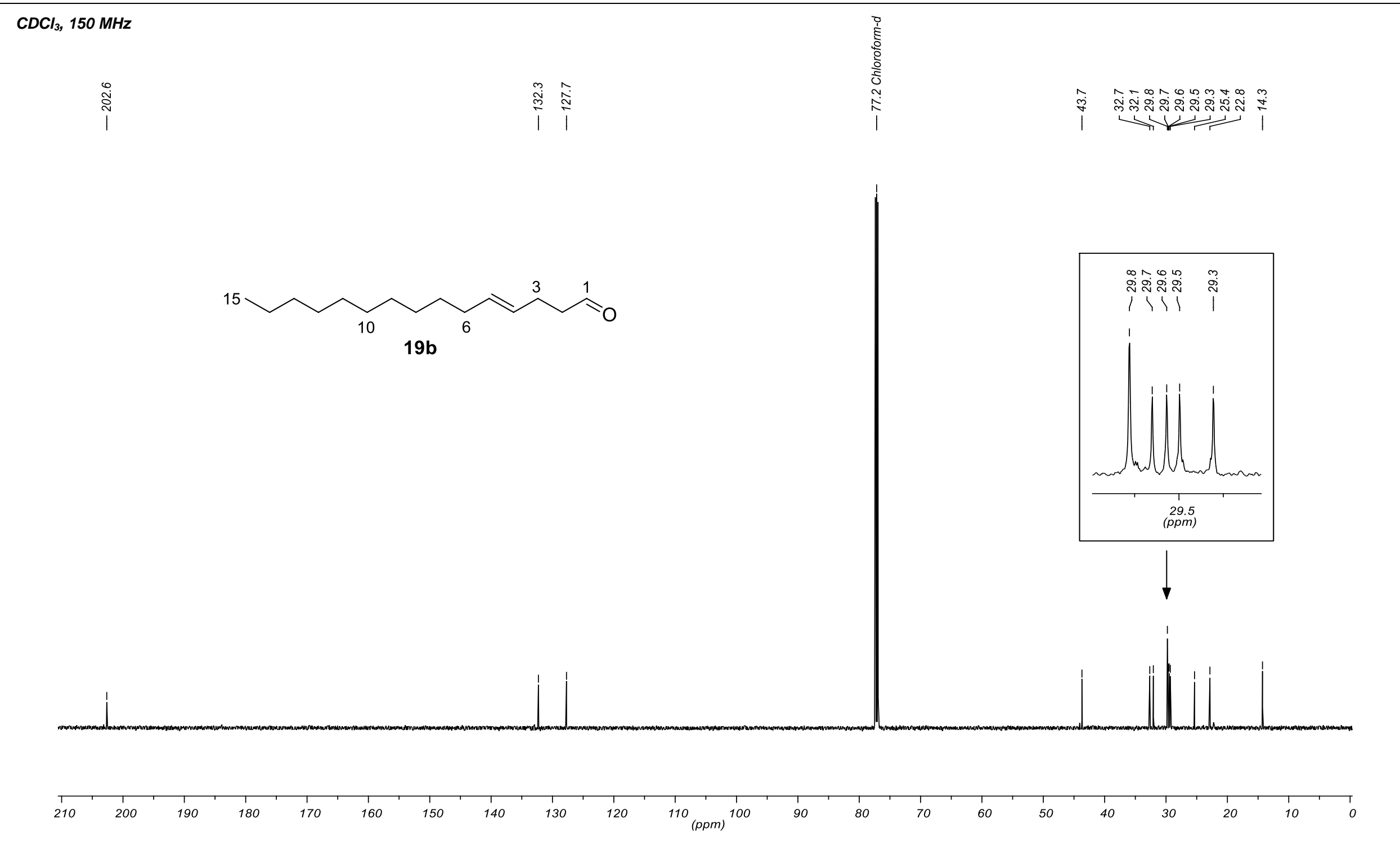




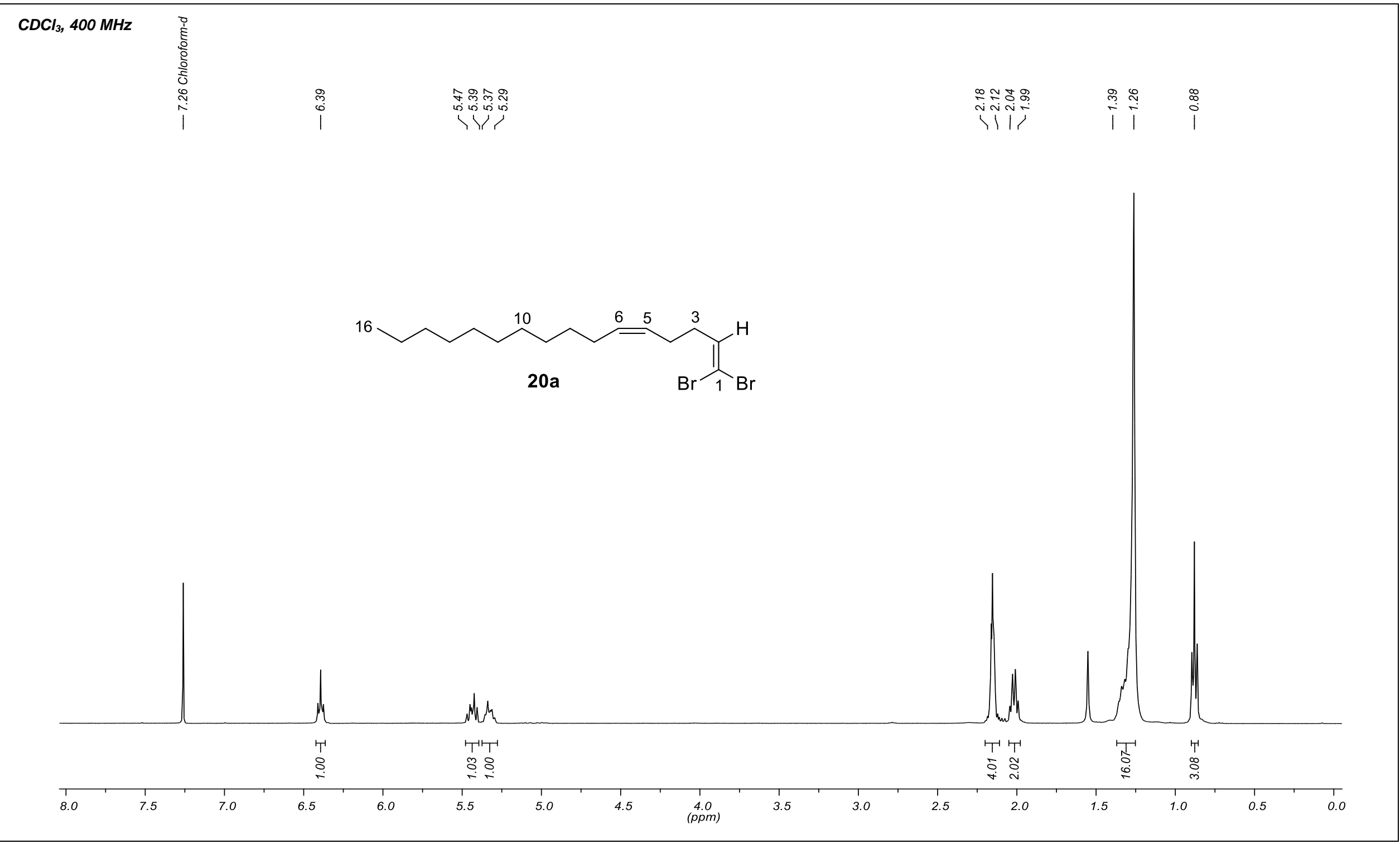




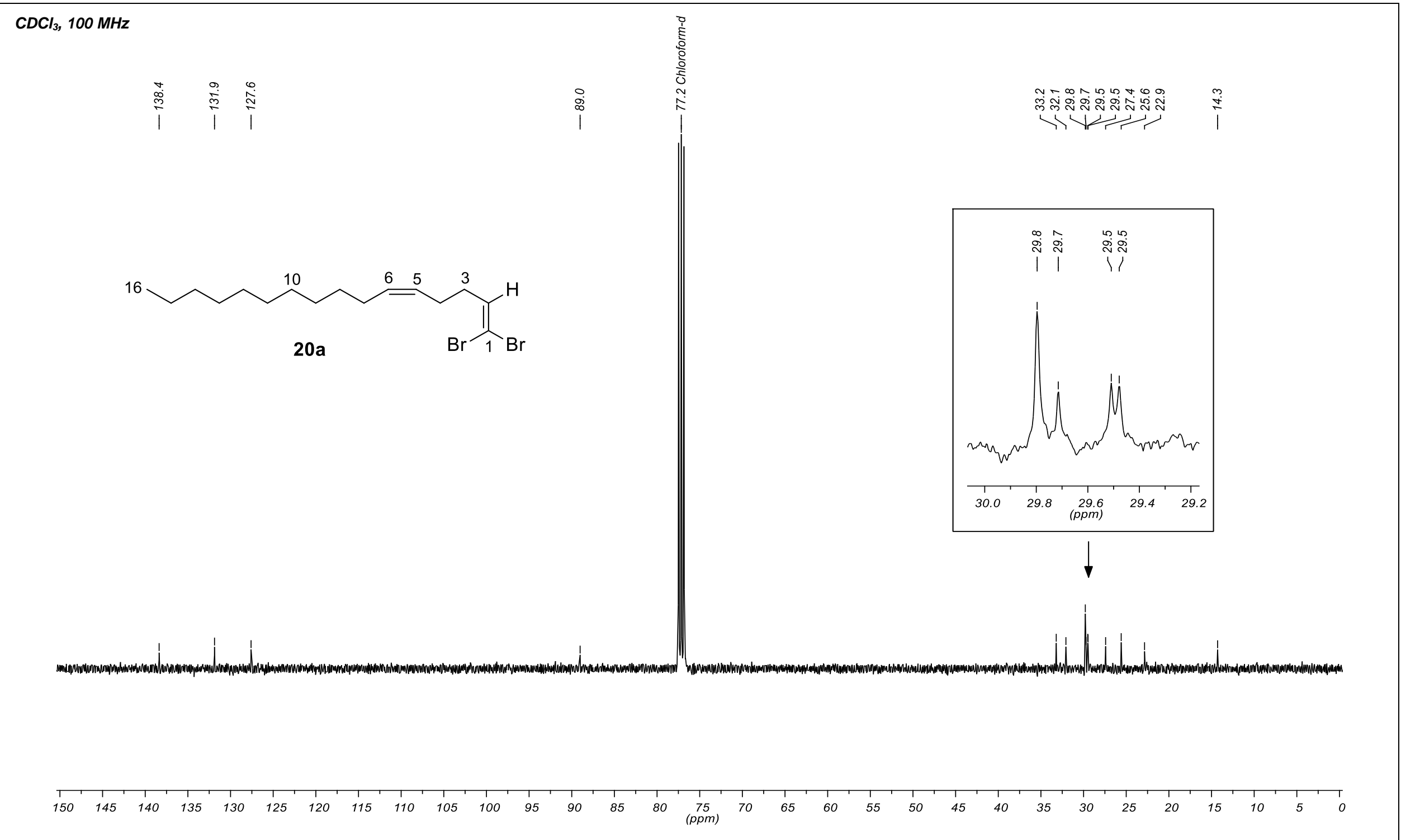




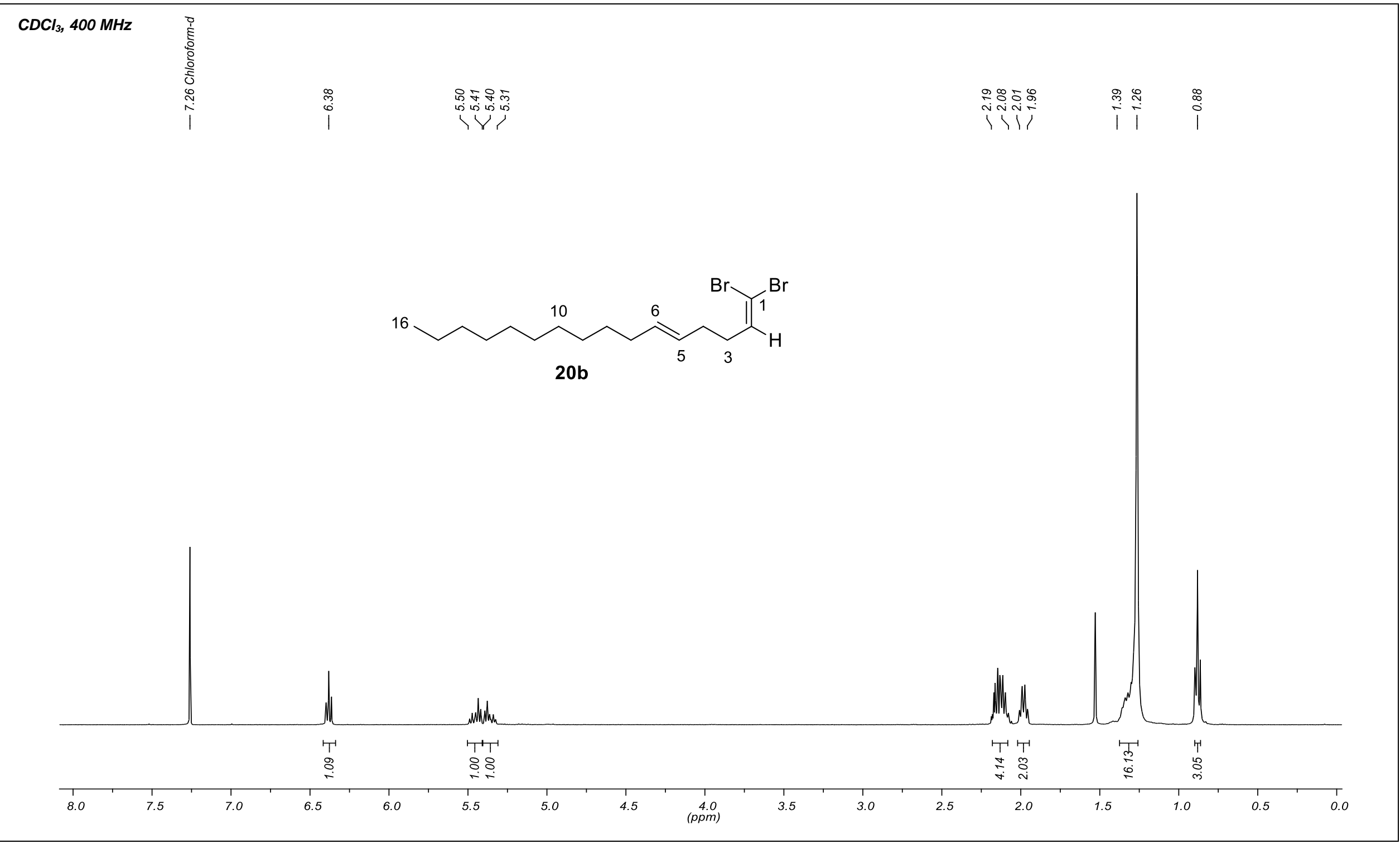




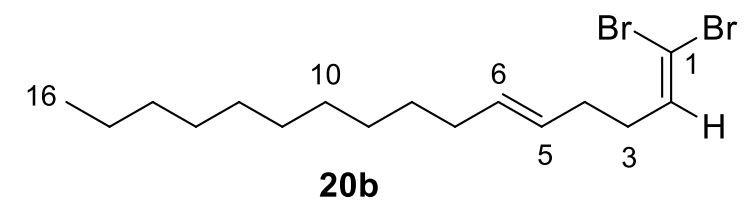

20b
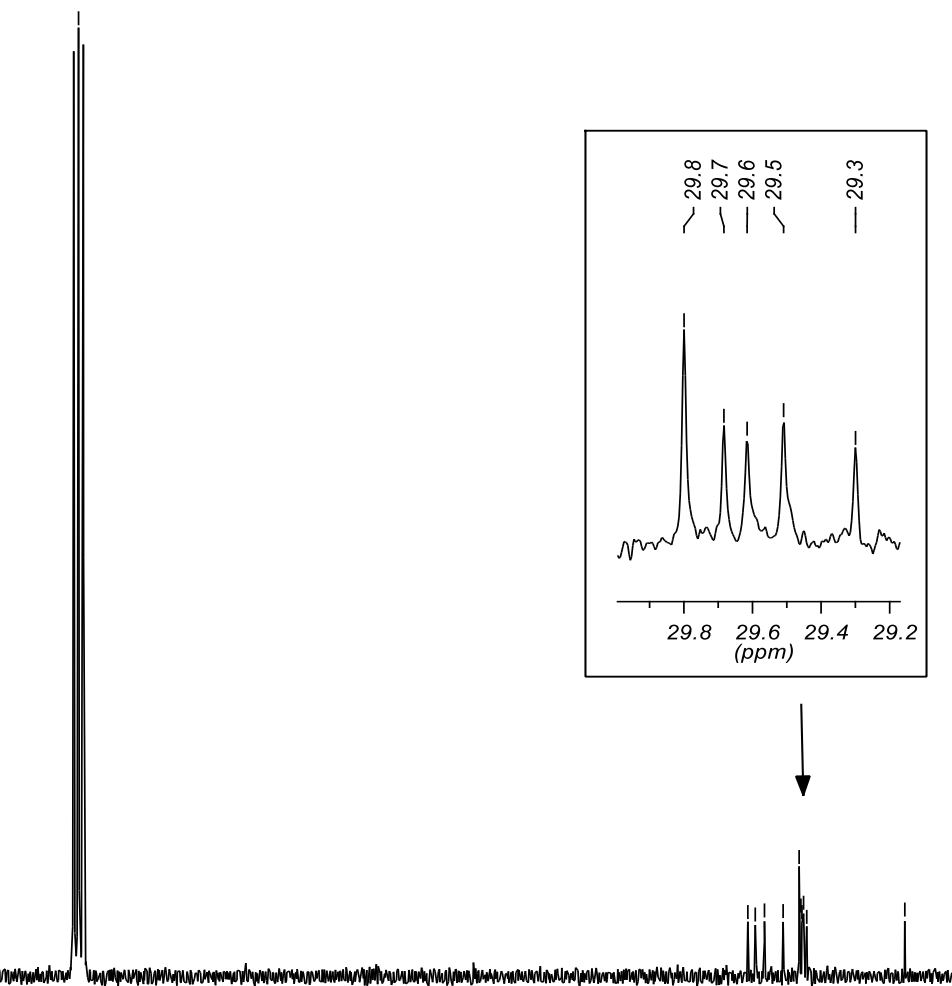

(t)

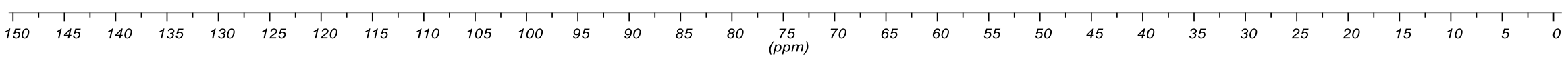




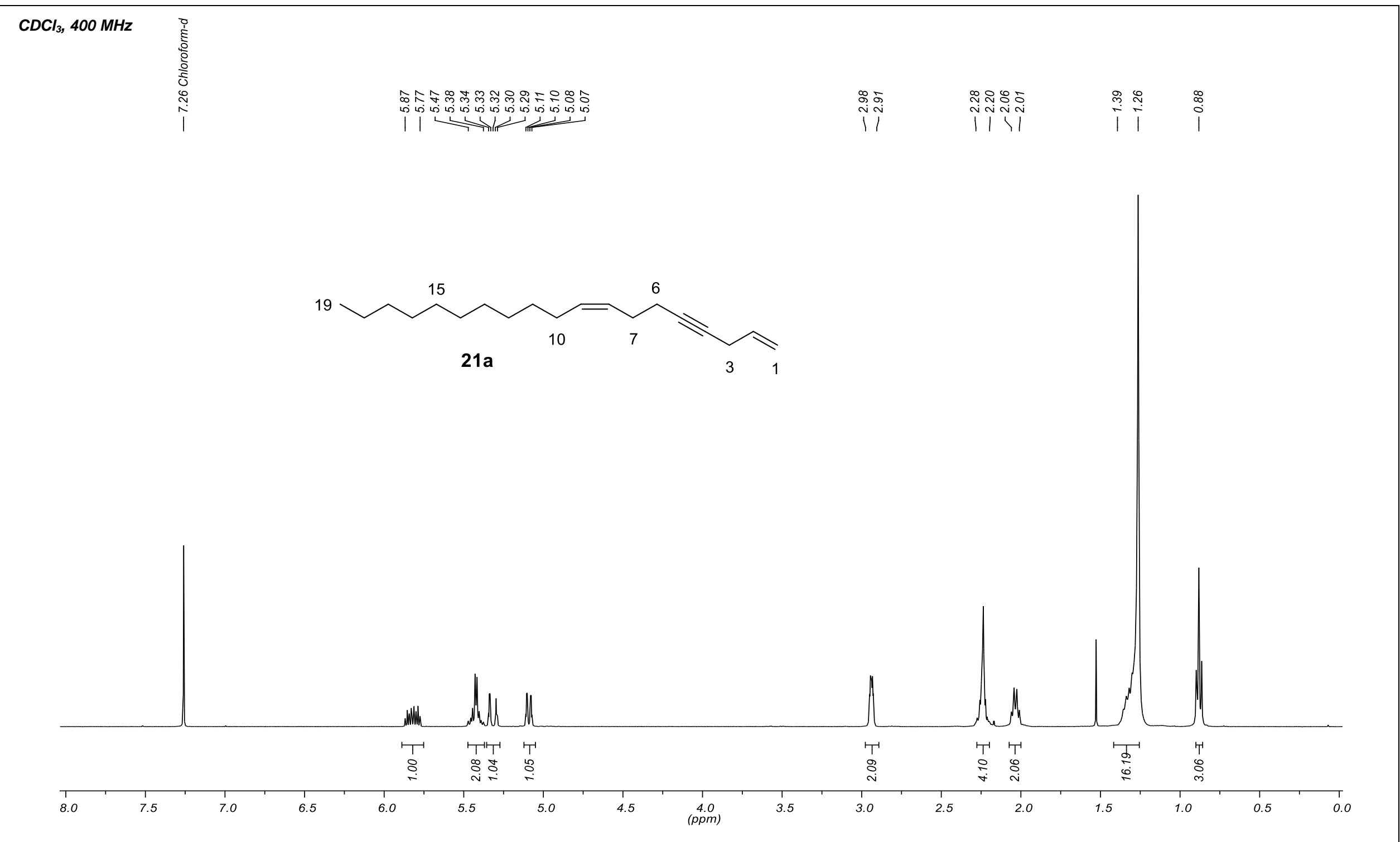




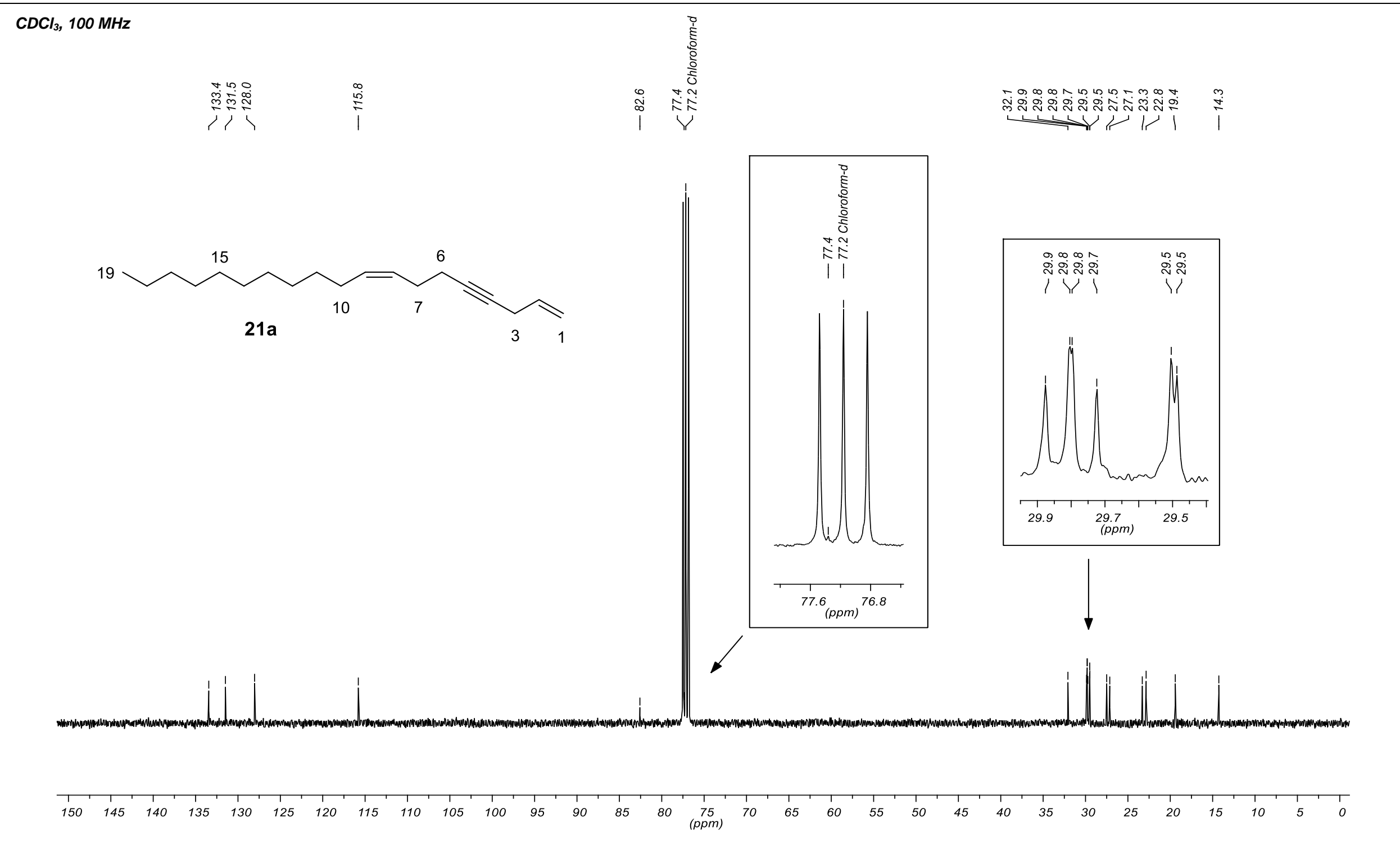




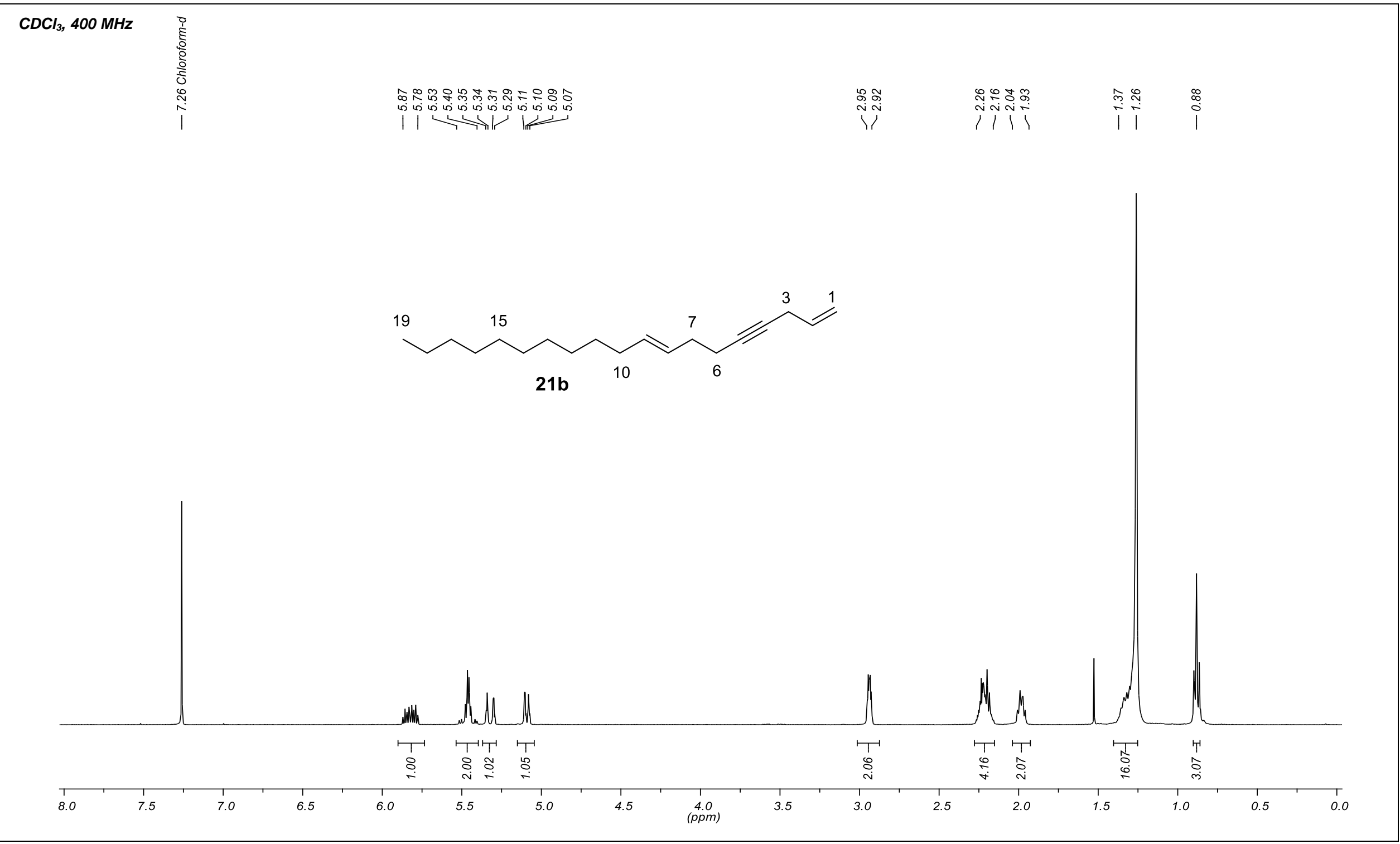




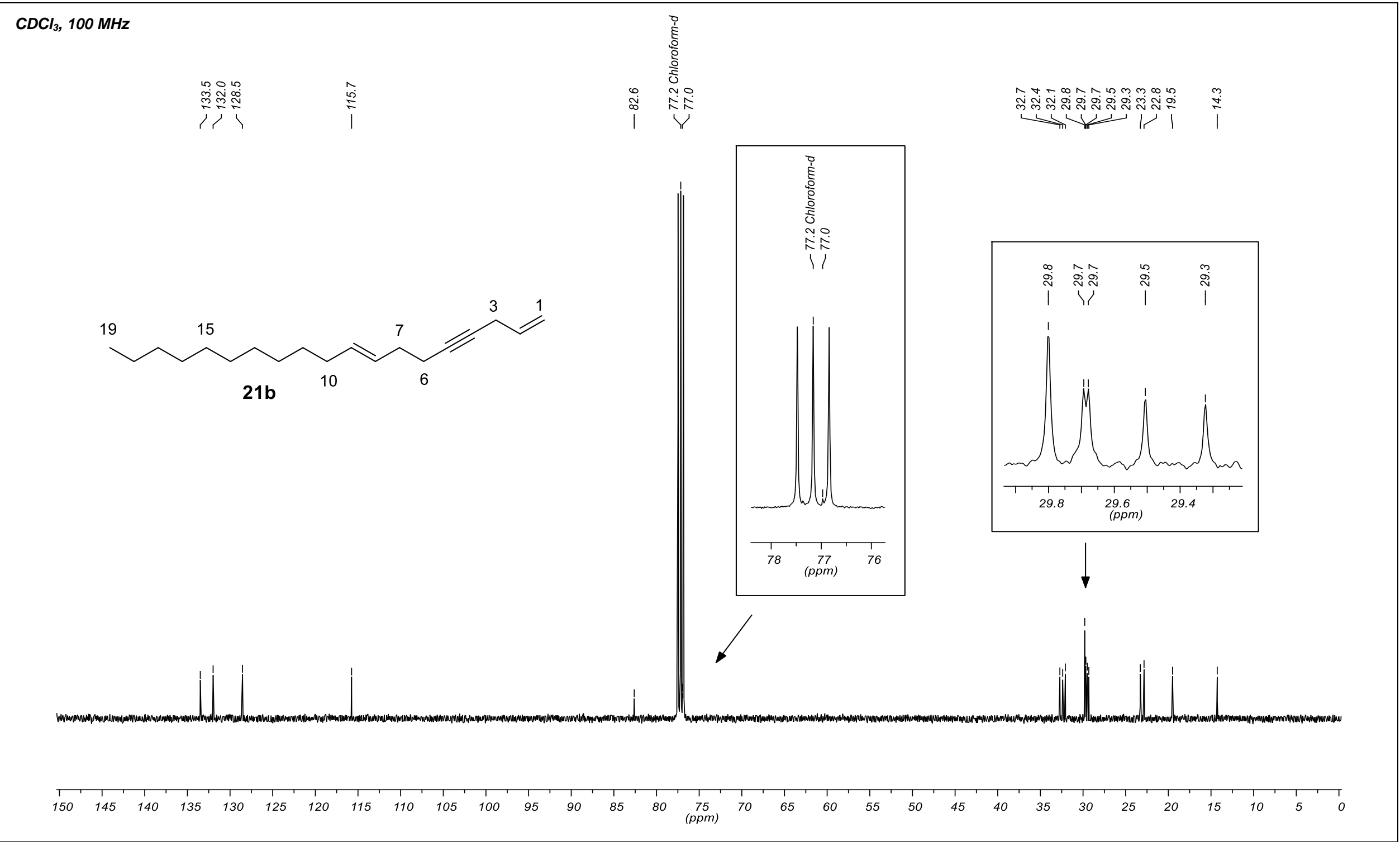




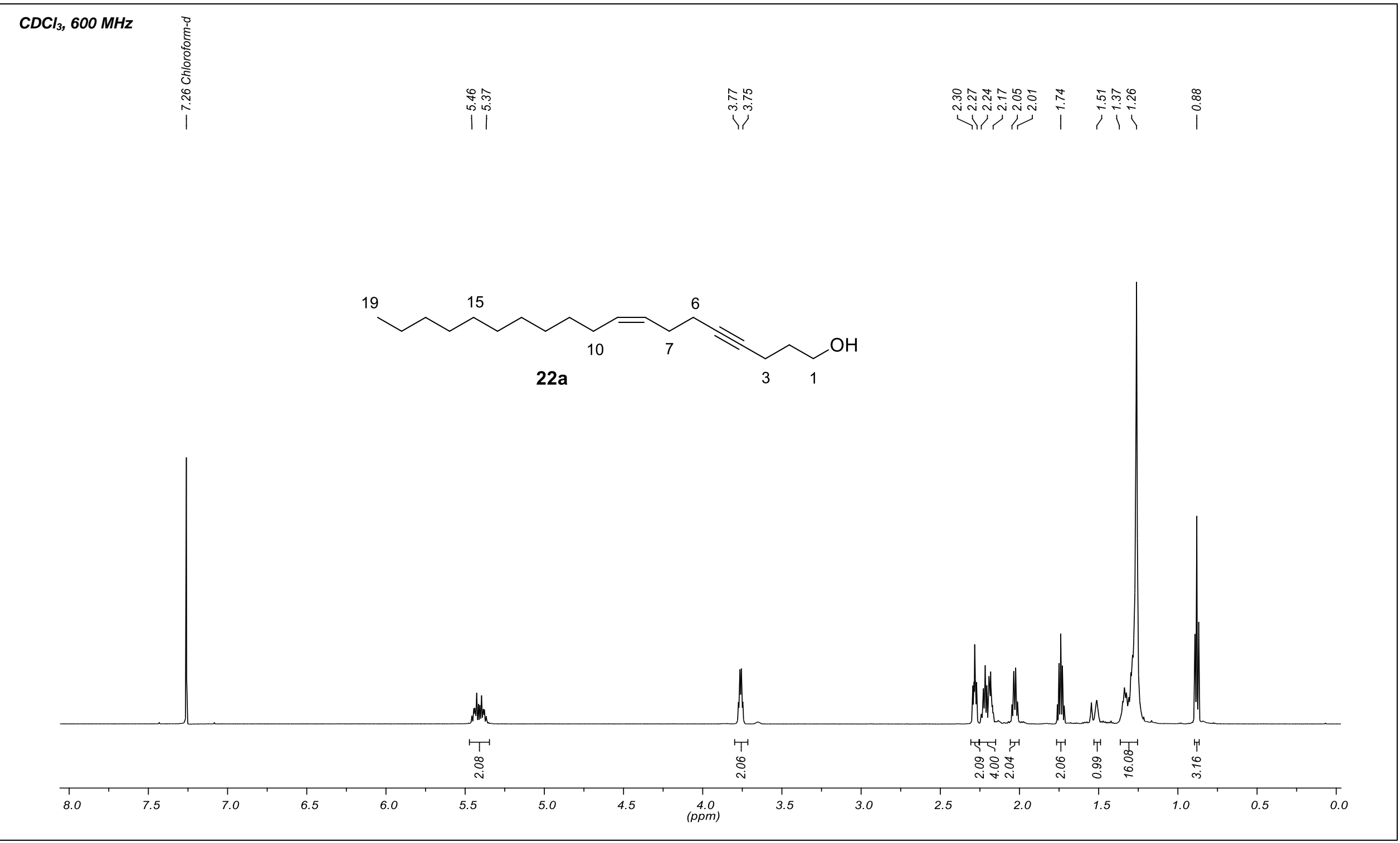




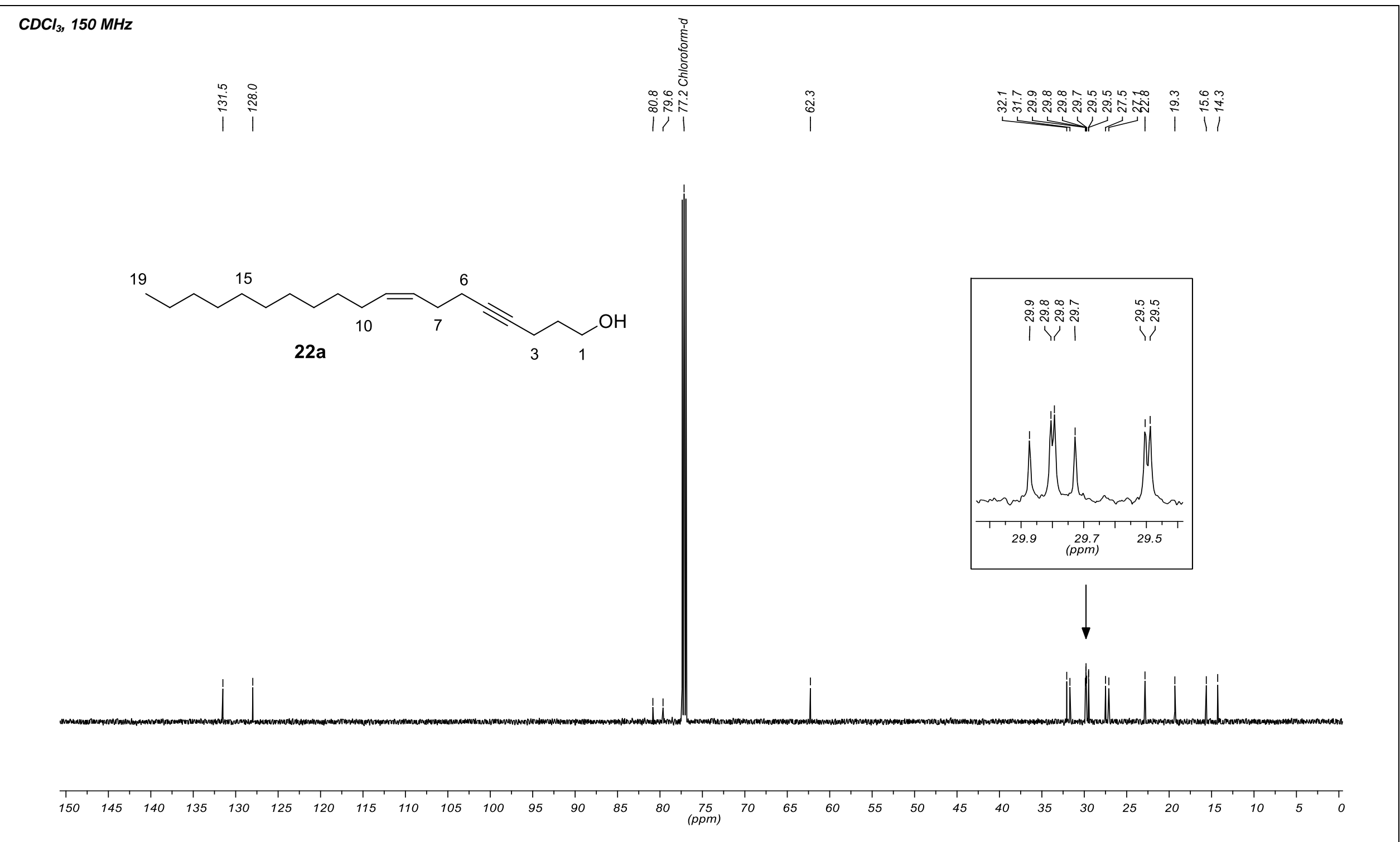




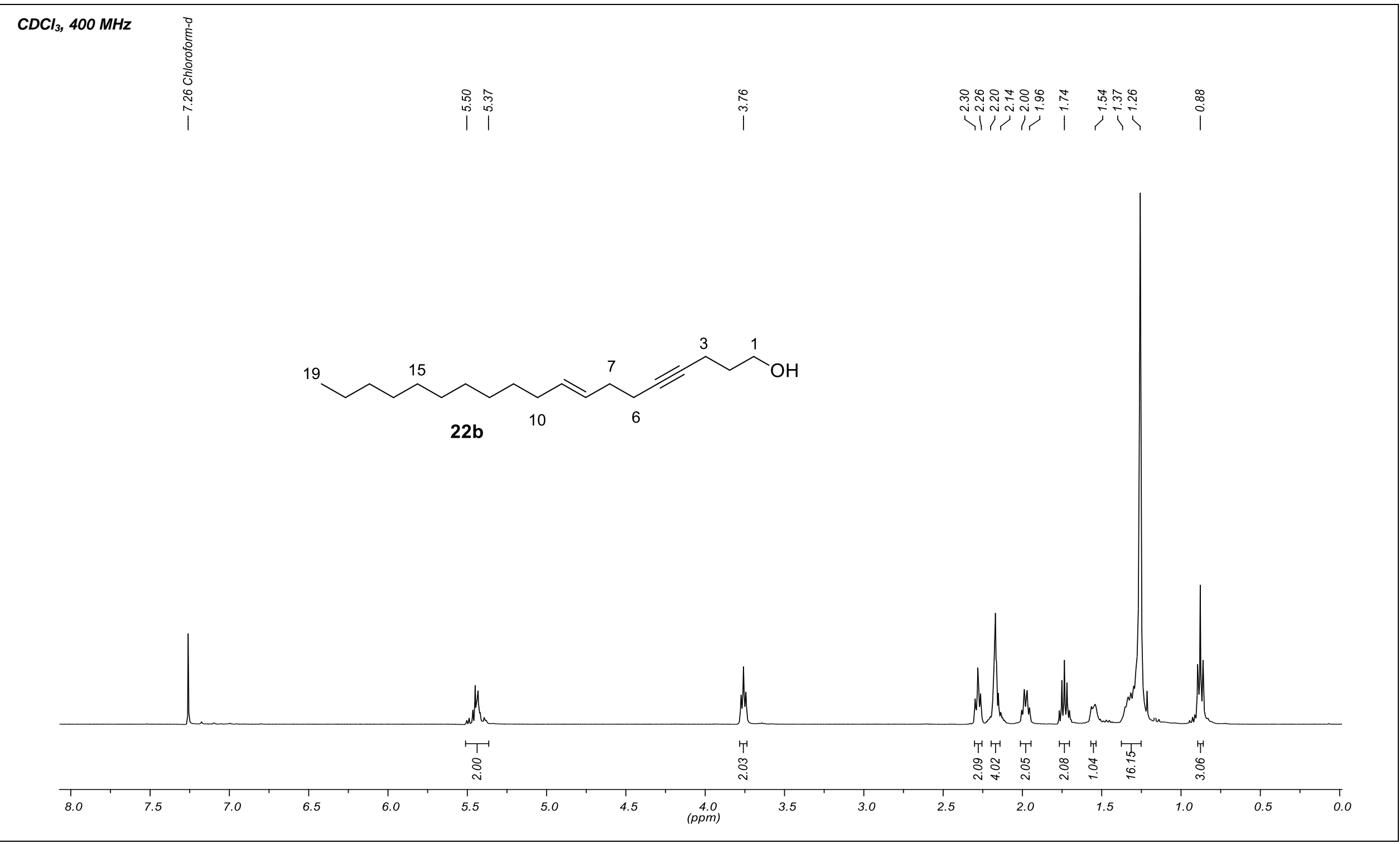




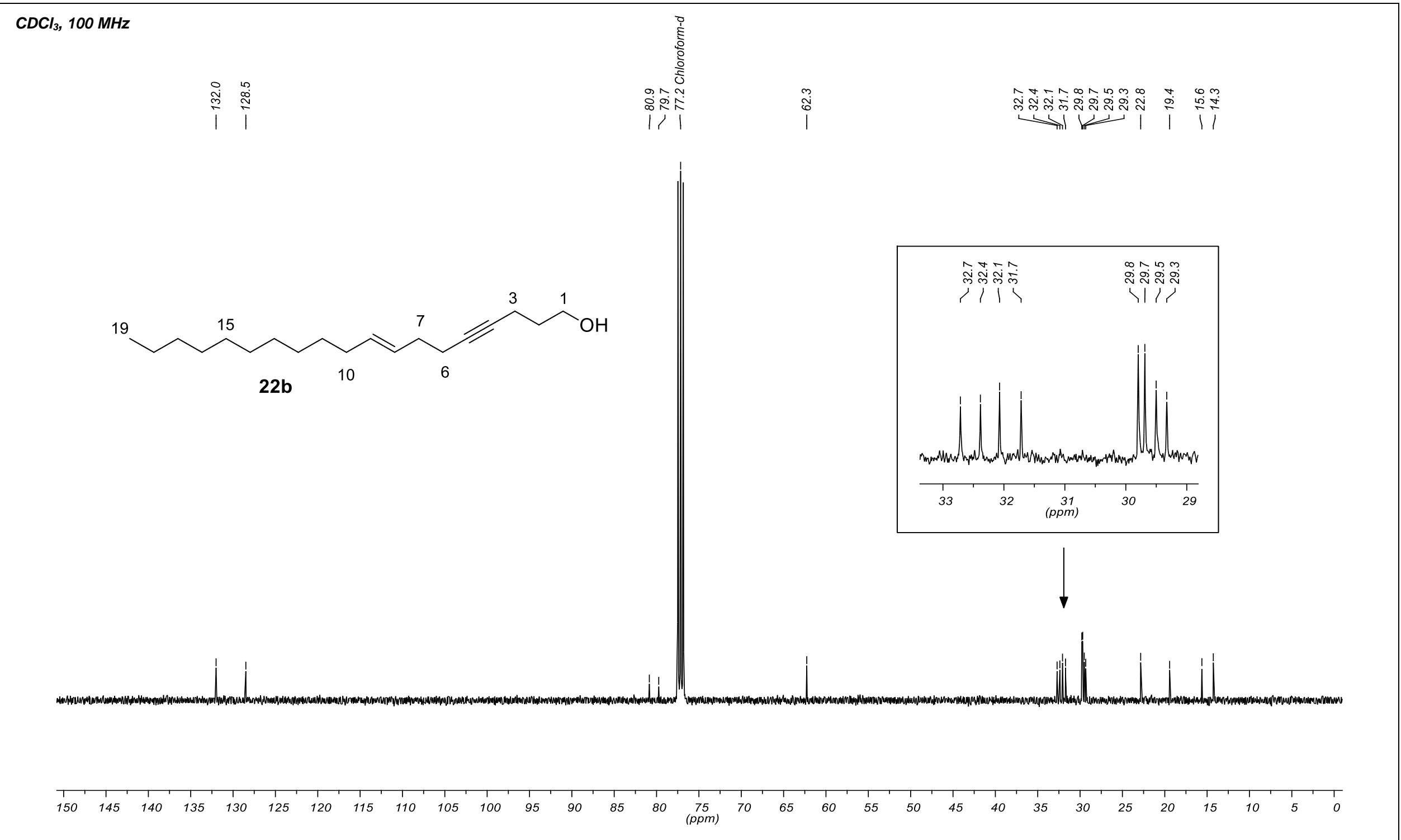




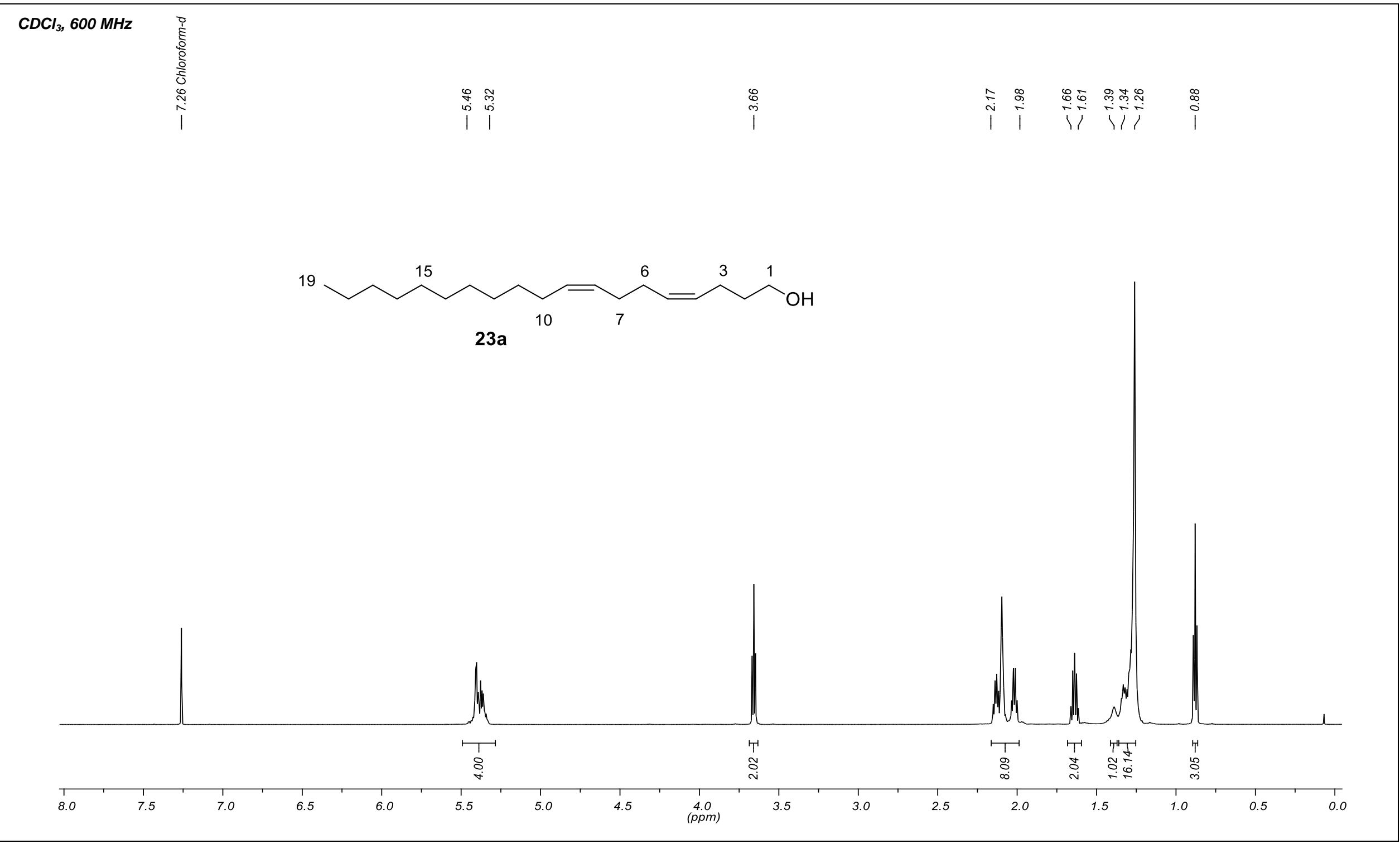




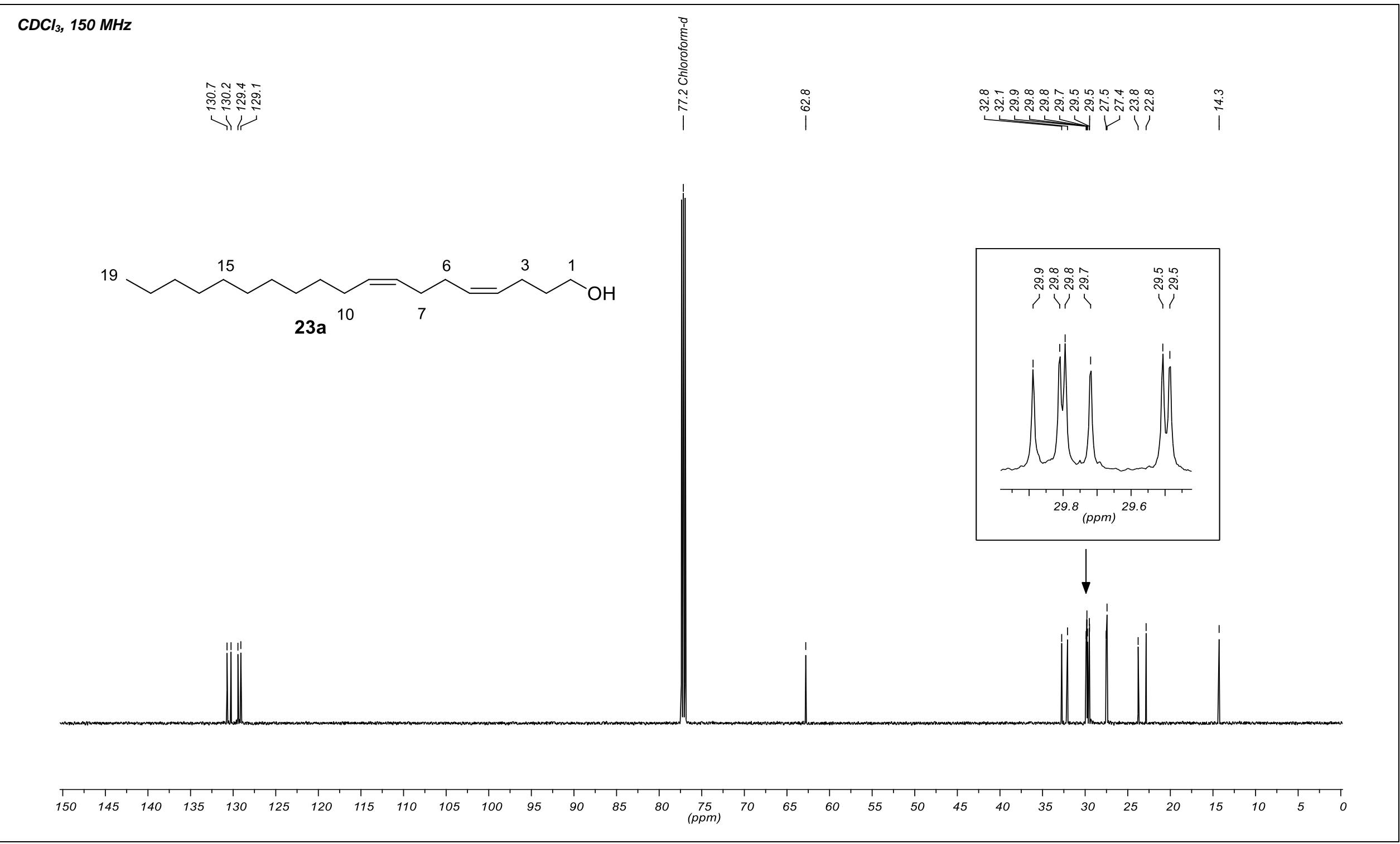




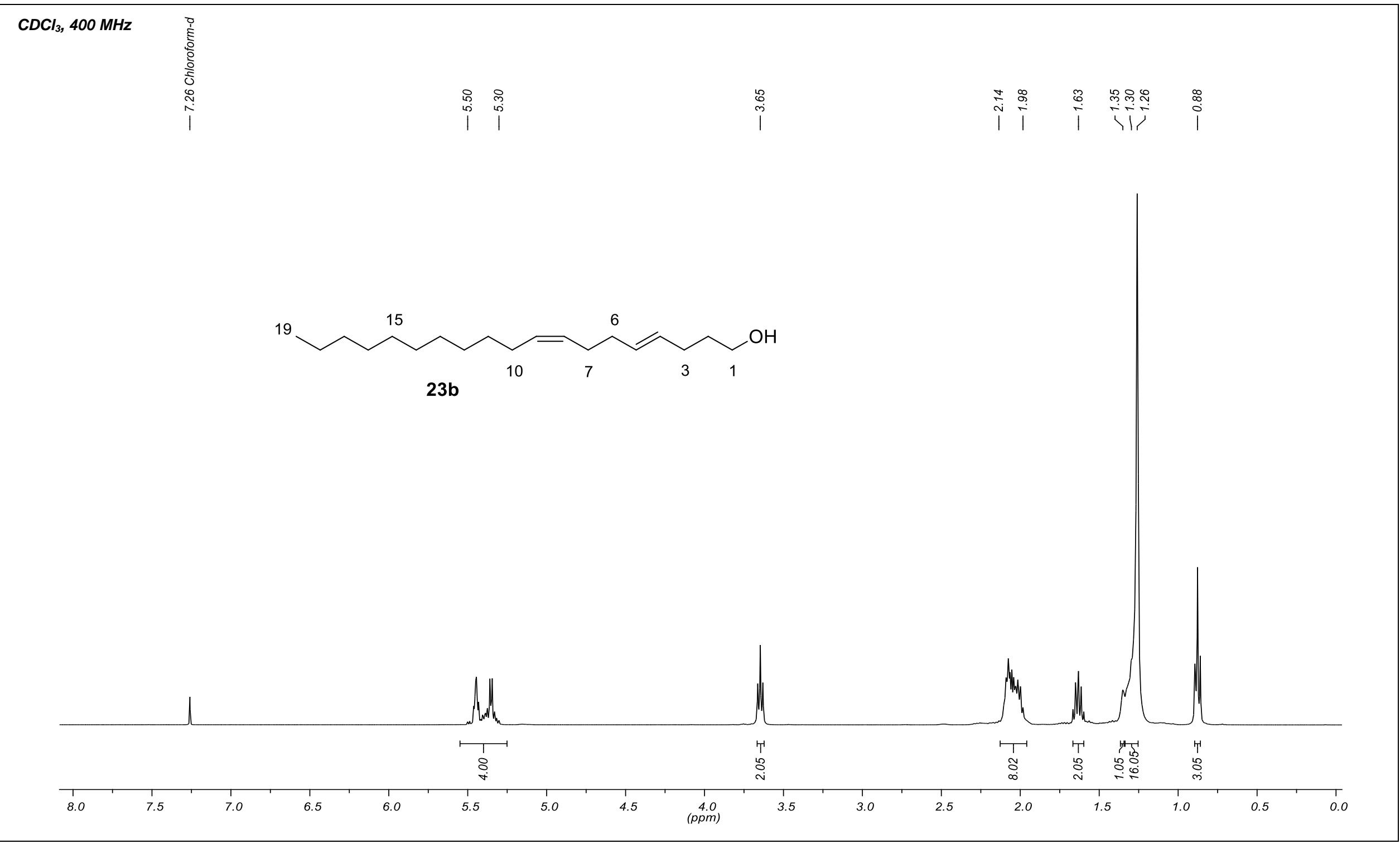




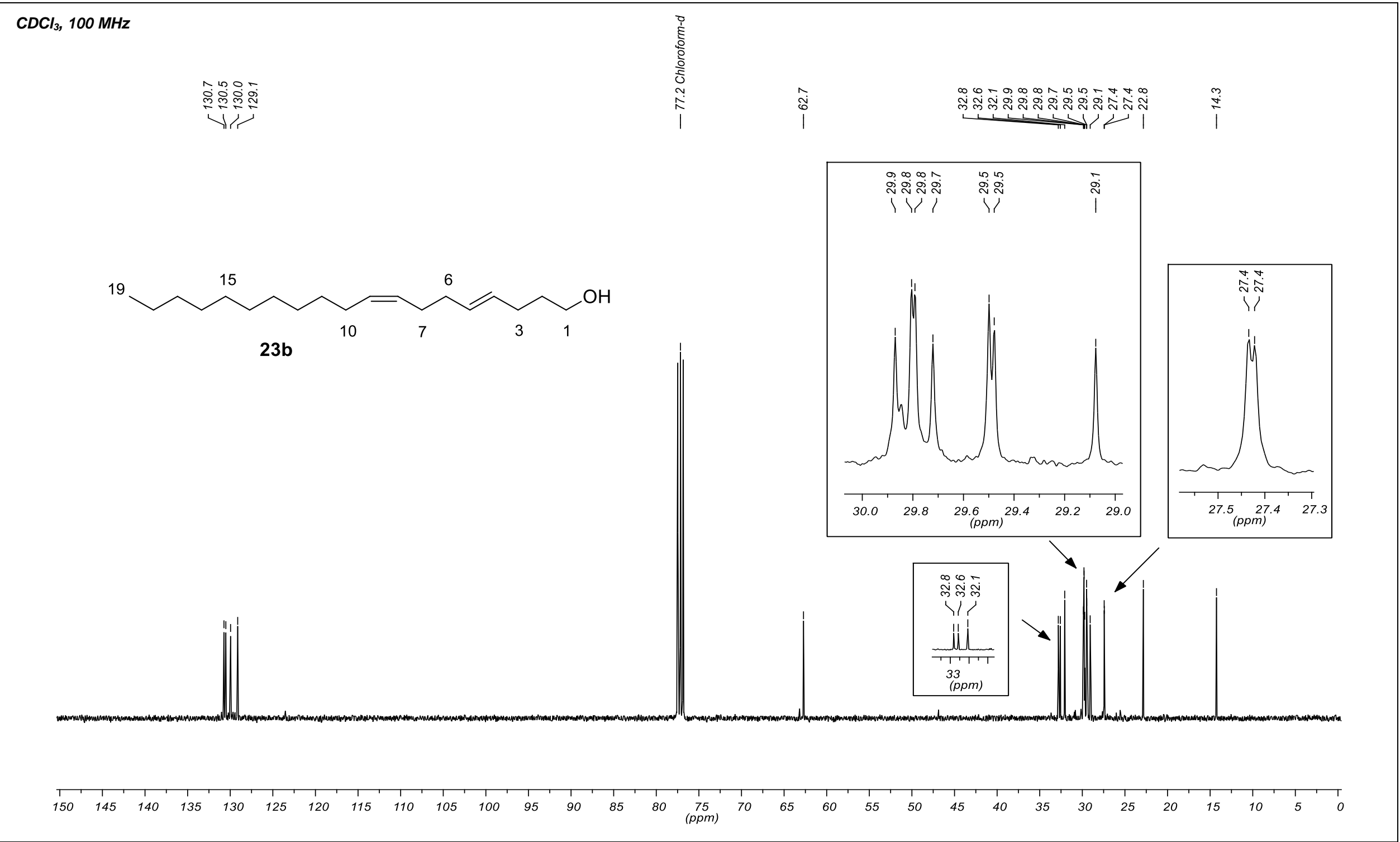




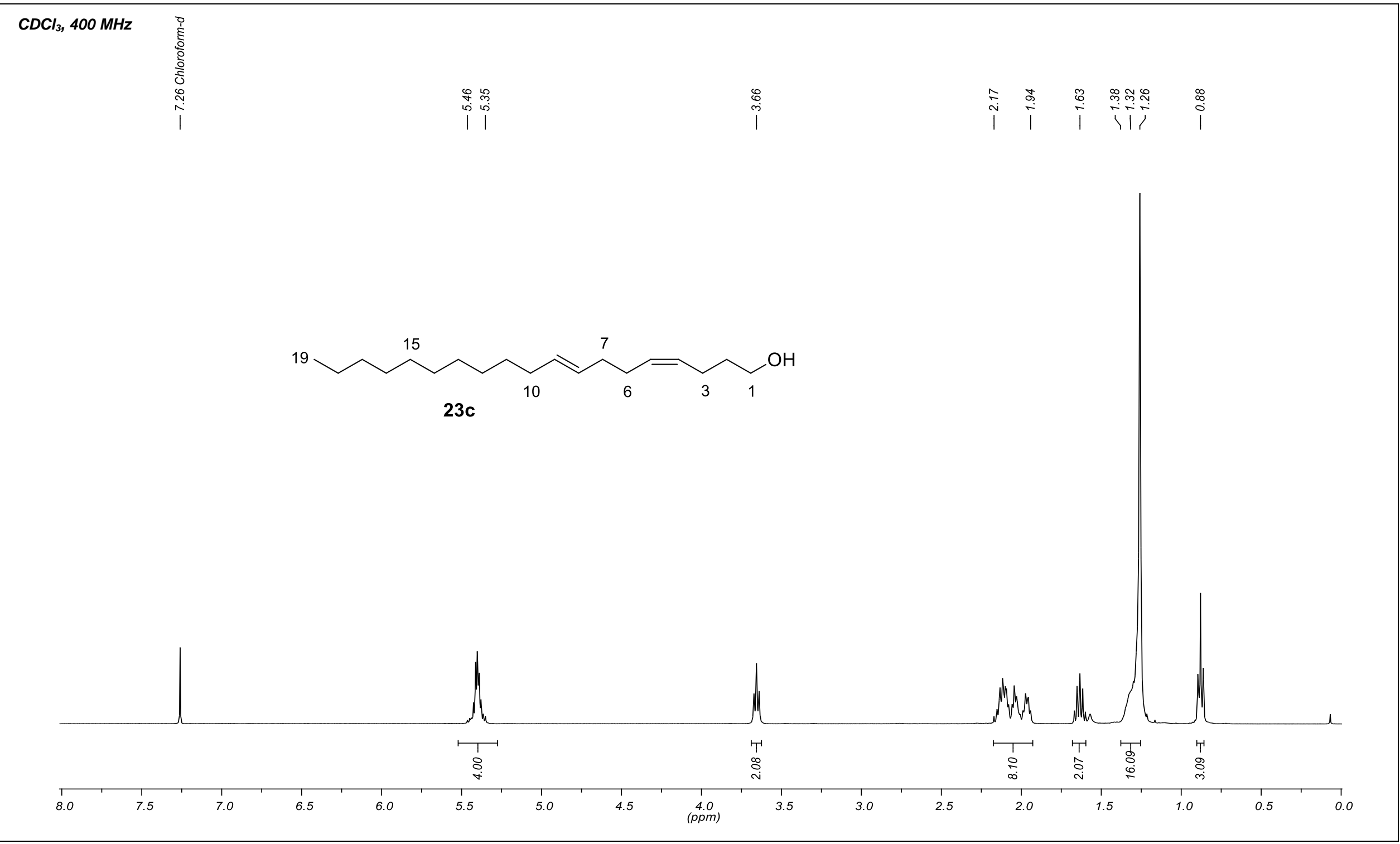




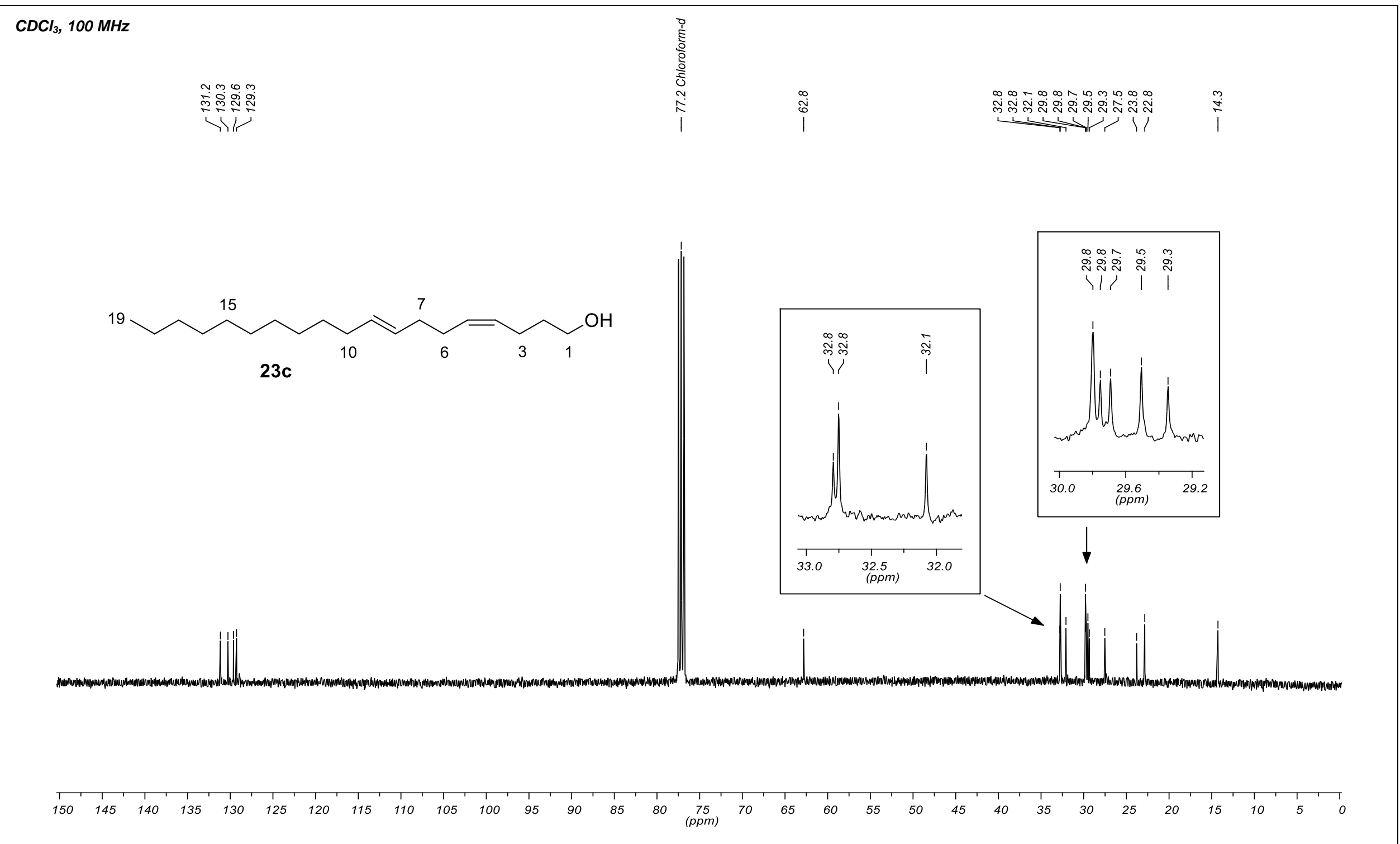




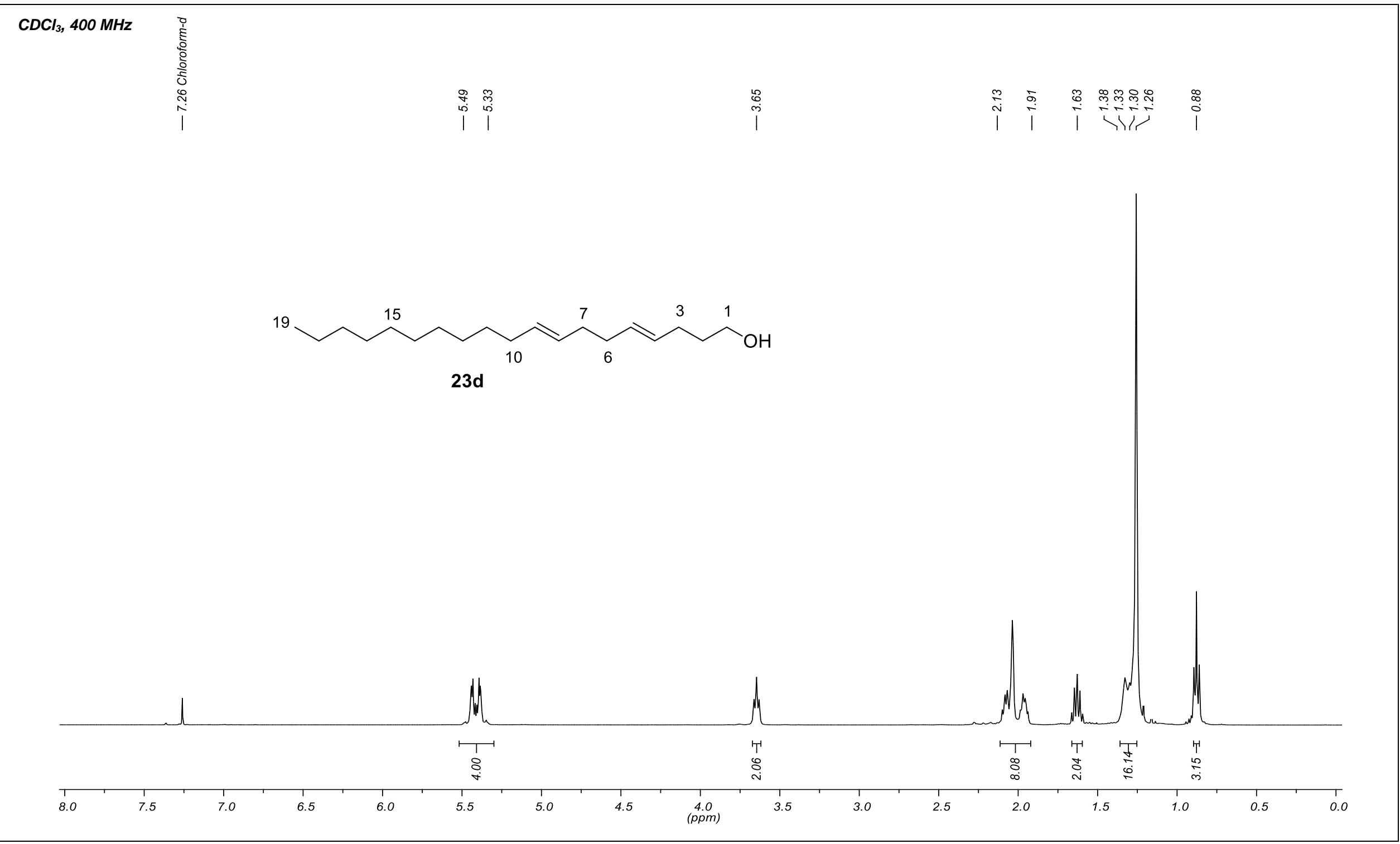




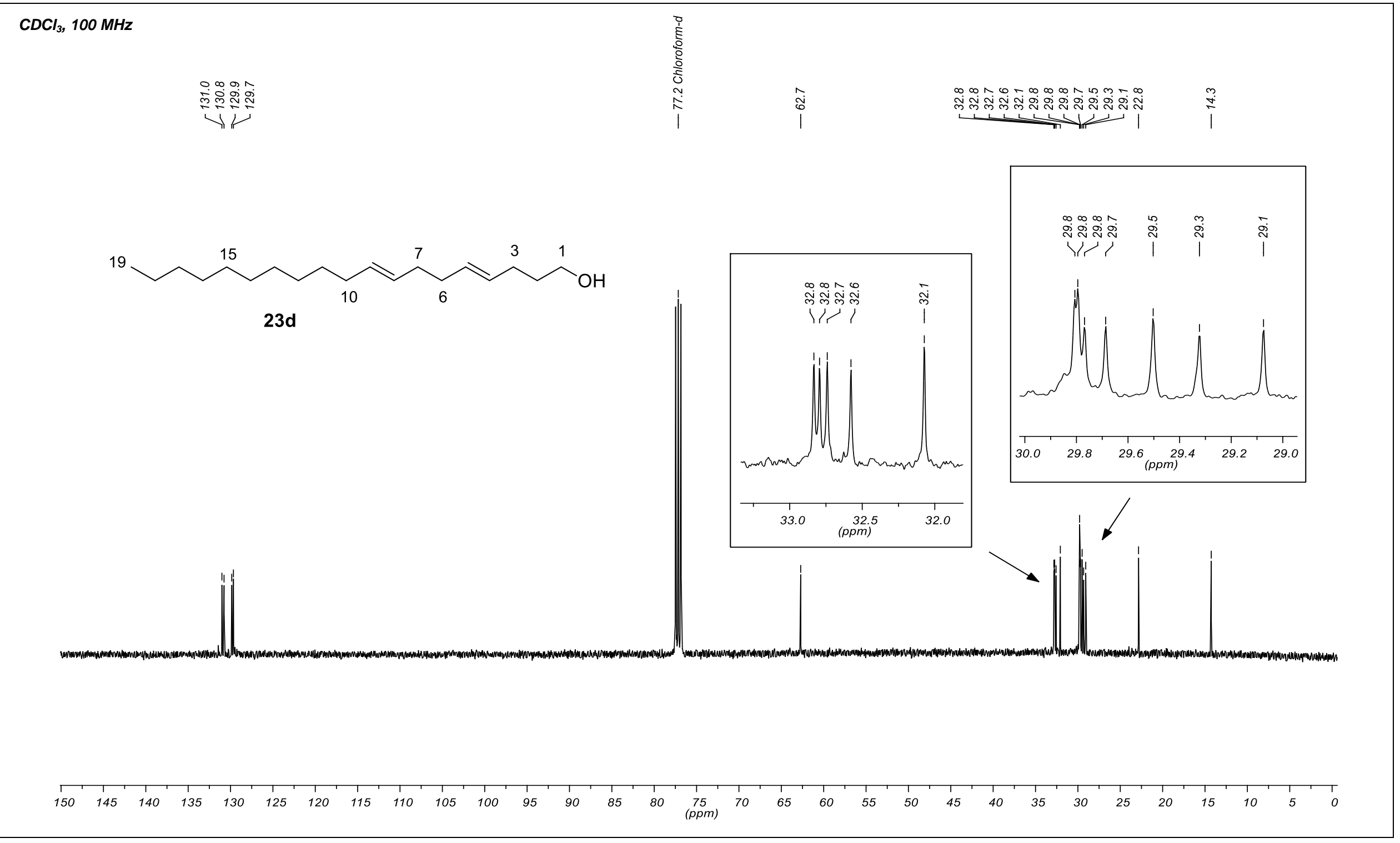



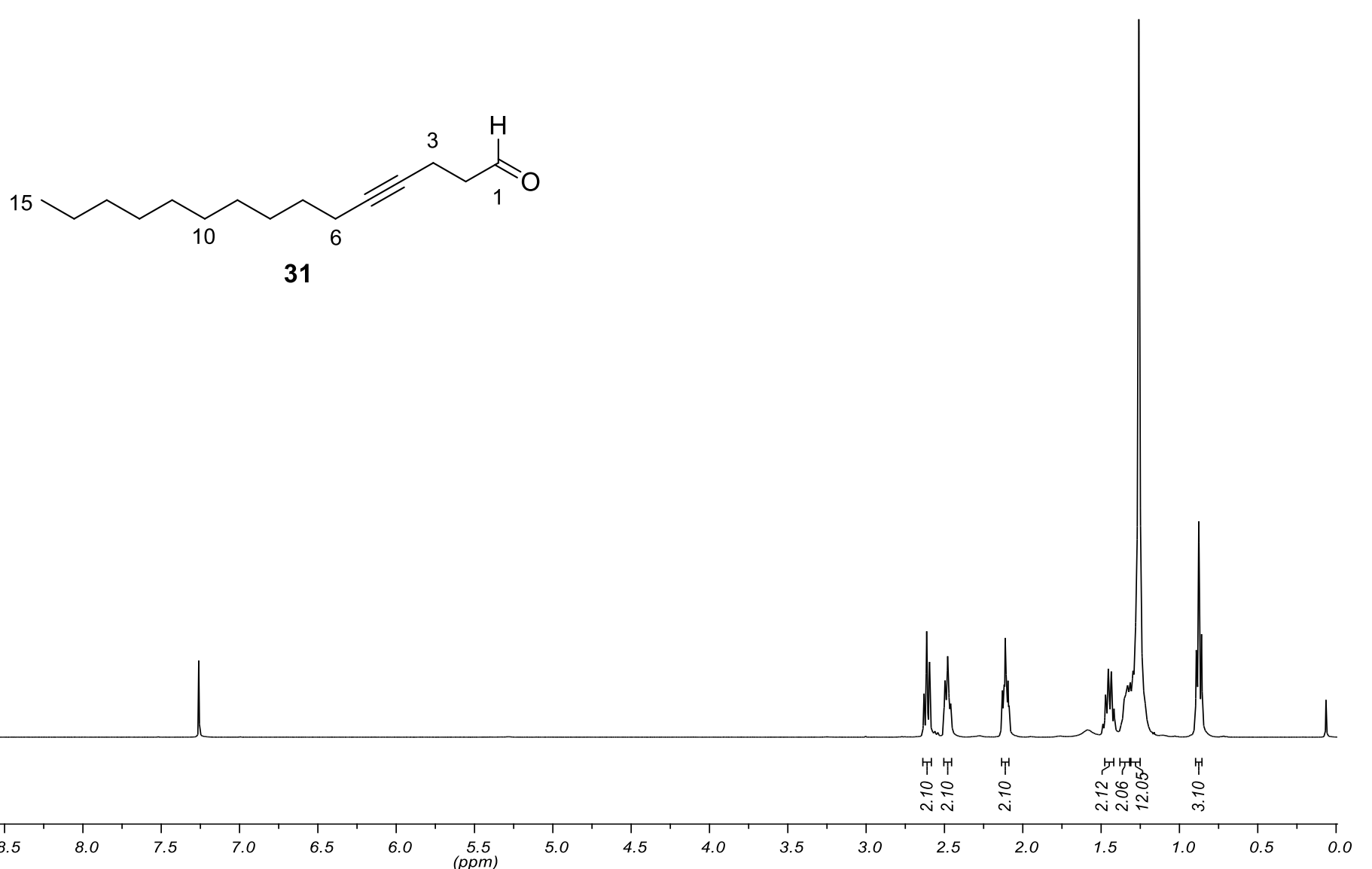


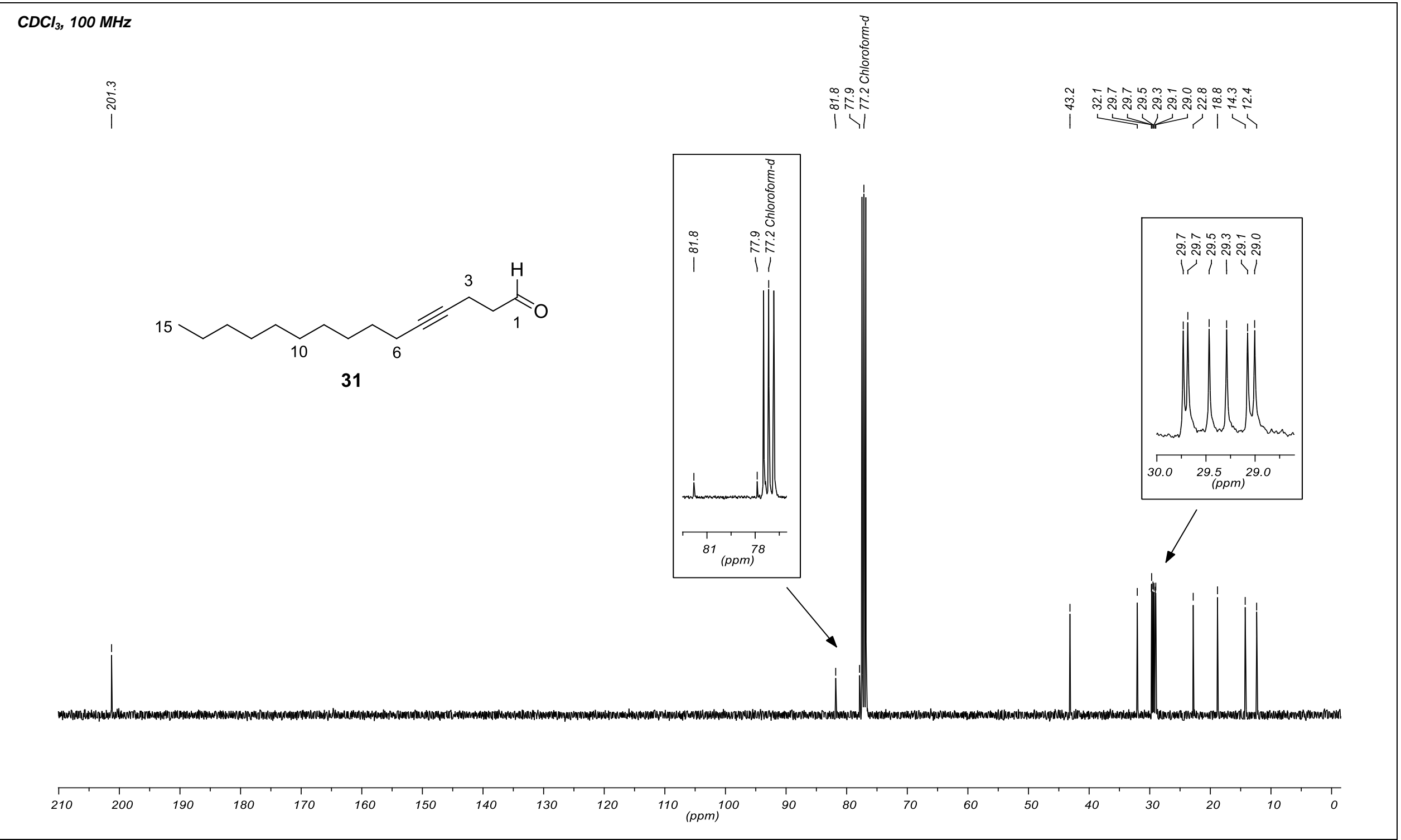




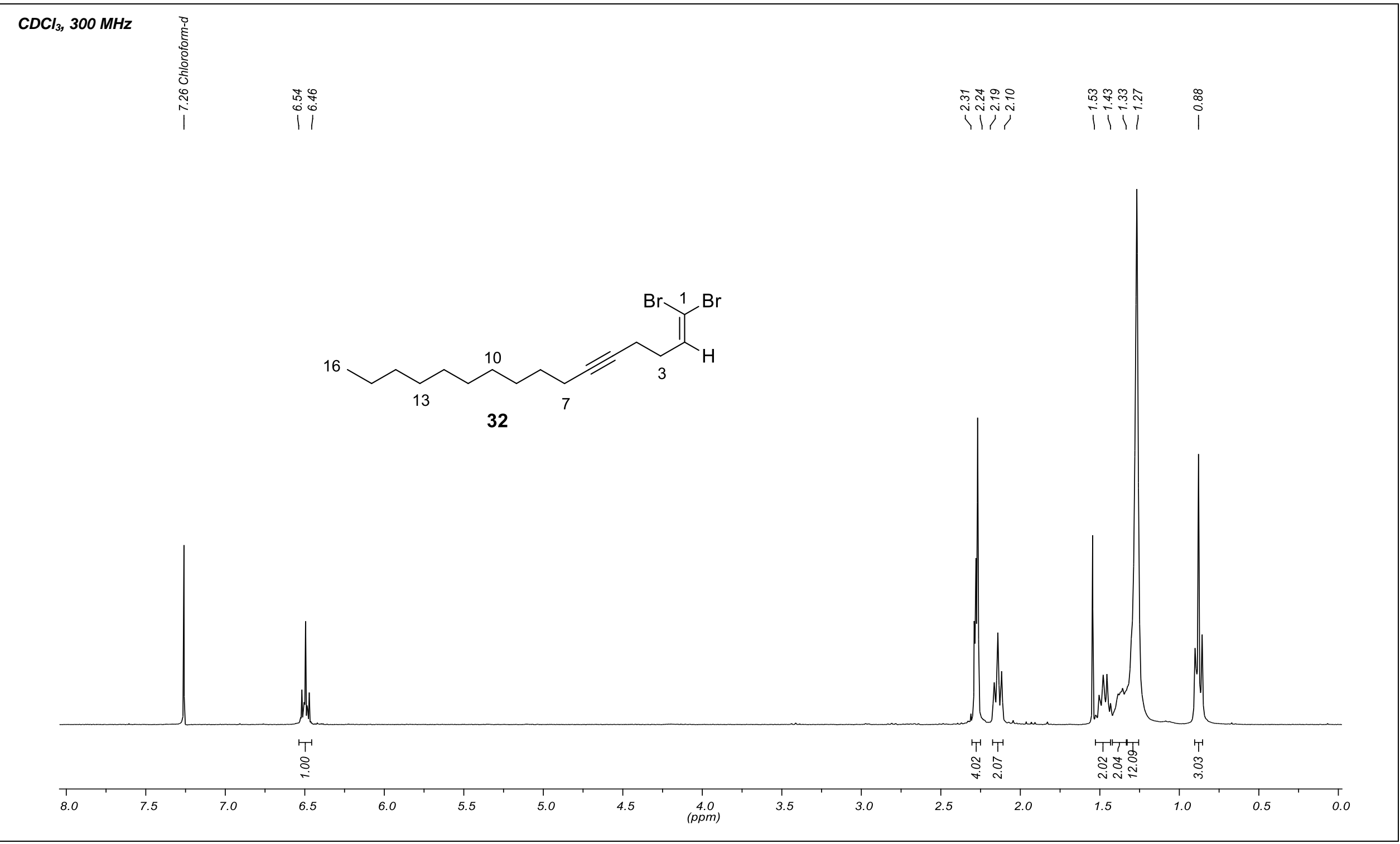




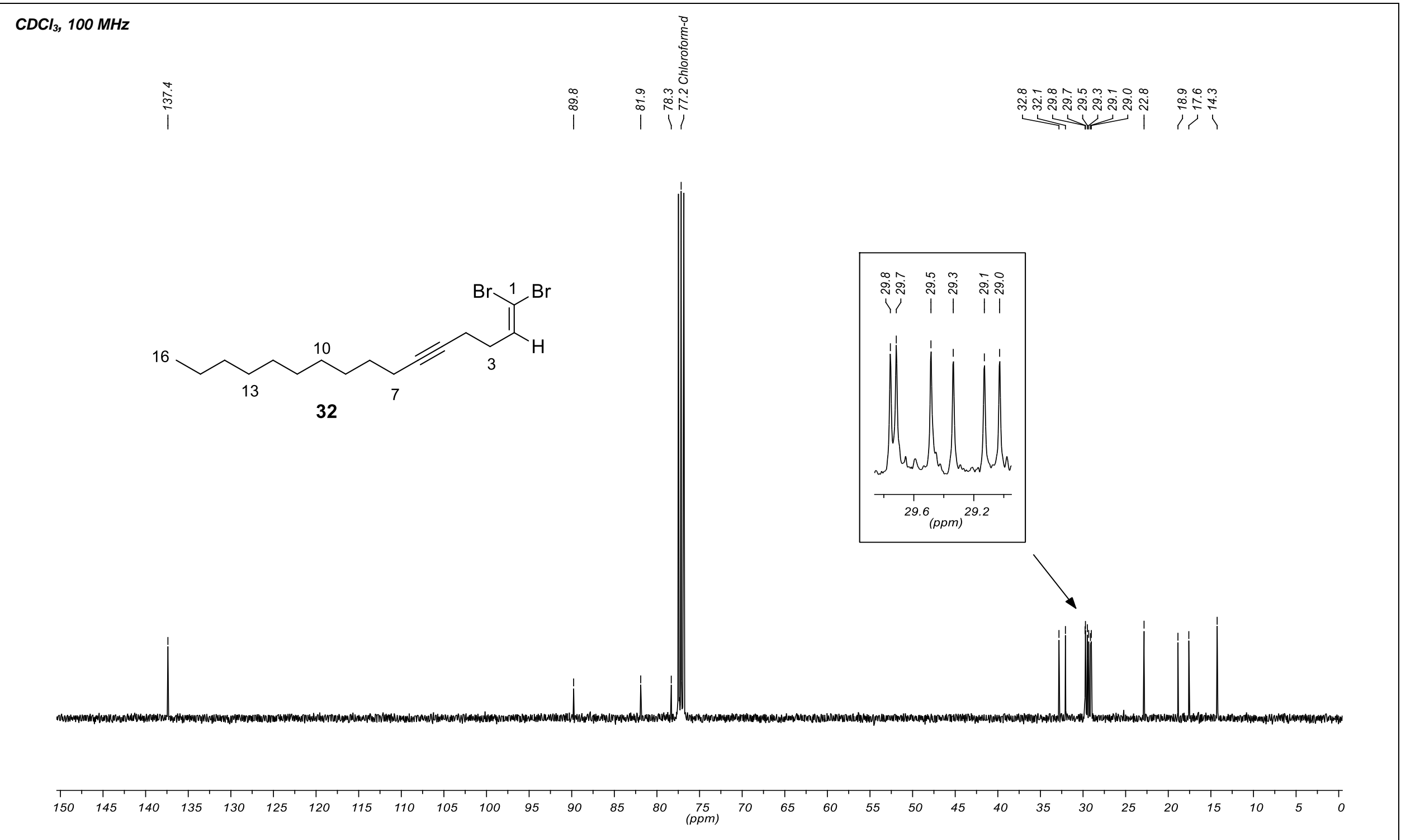




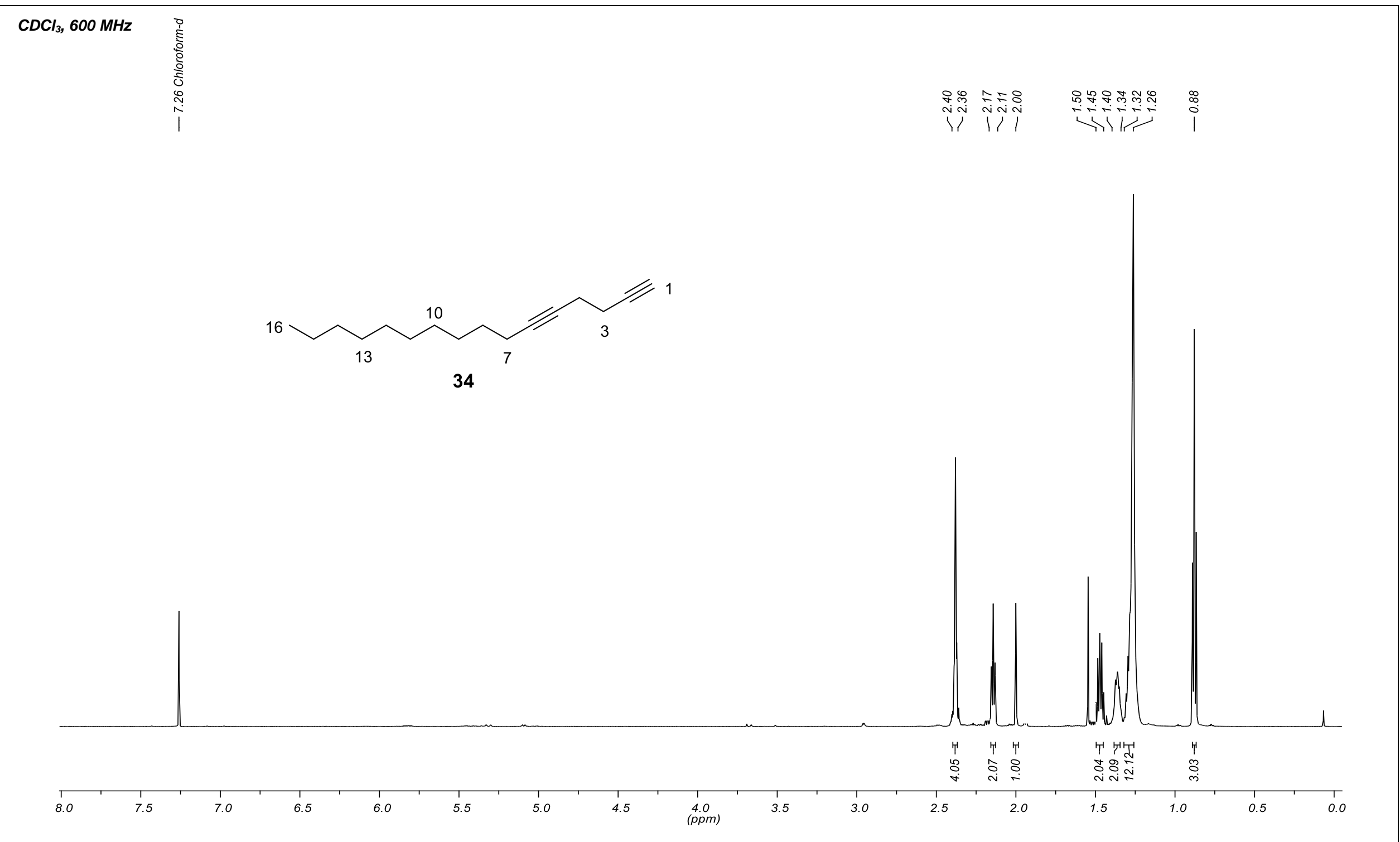




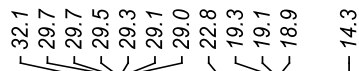

11 । ।
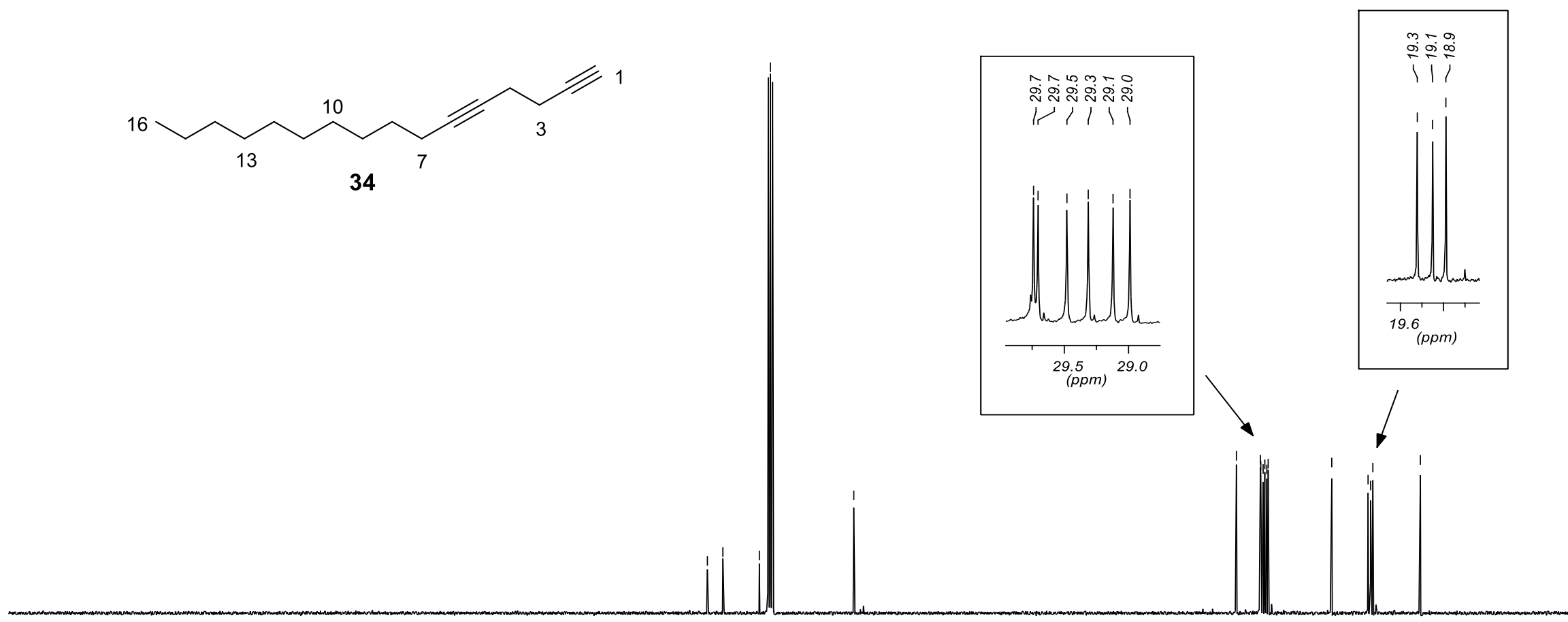

$80 \begin{gathered}75 \\ (p p m)\end{gathered} 70 \quad 65 \quad 60$
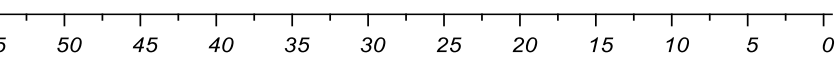


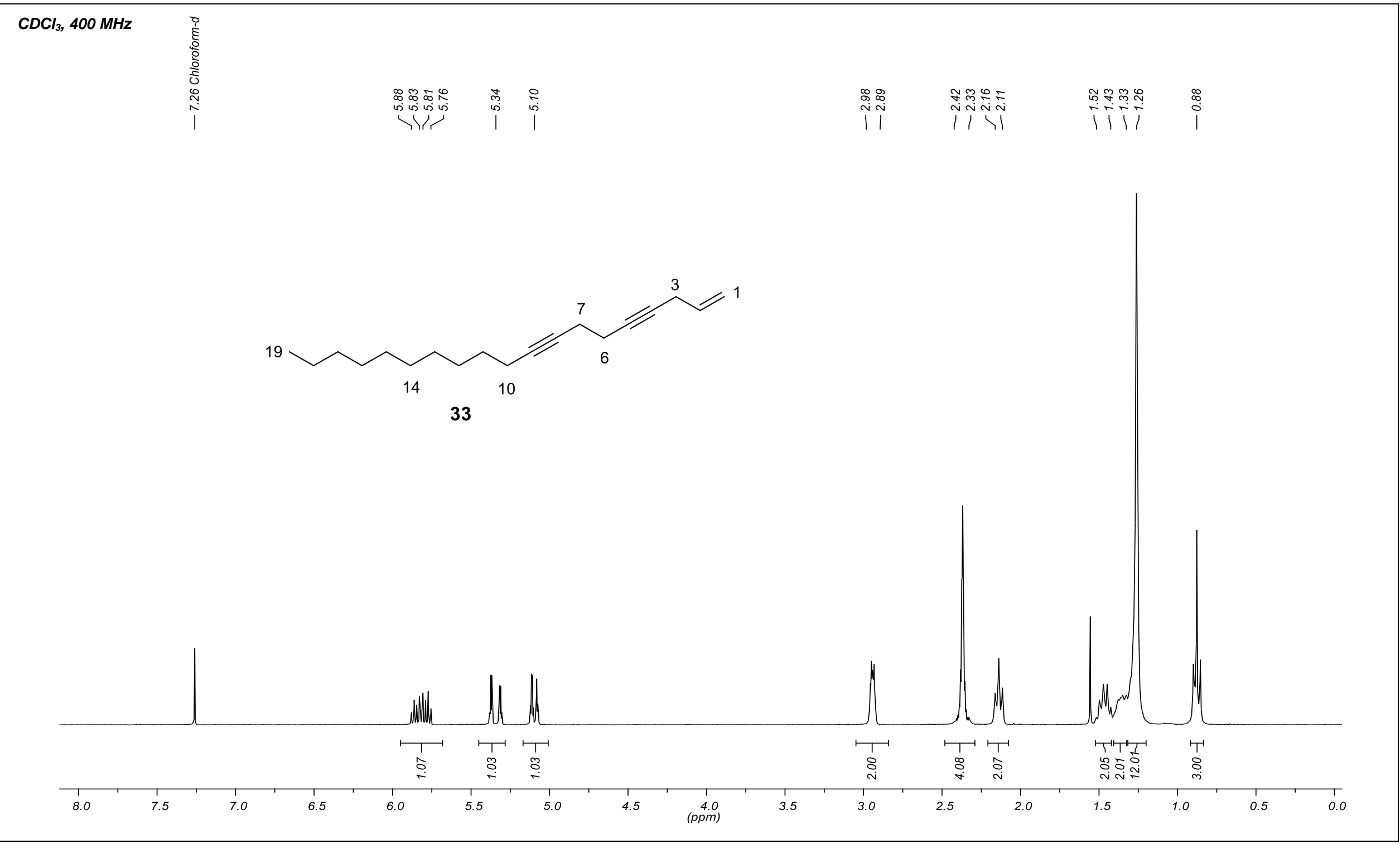




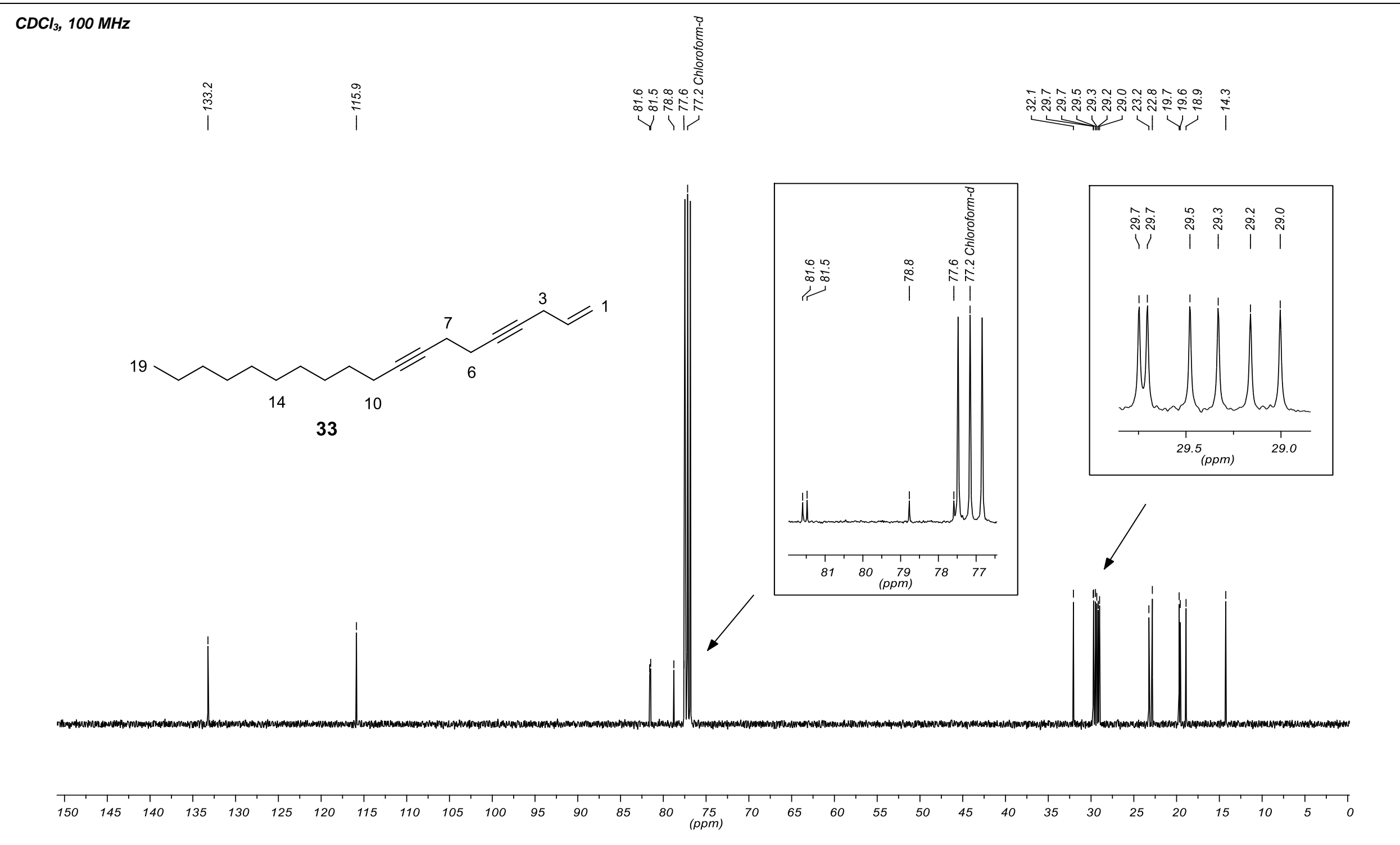




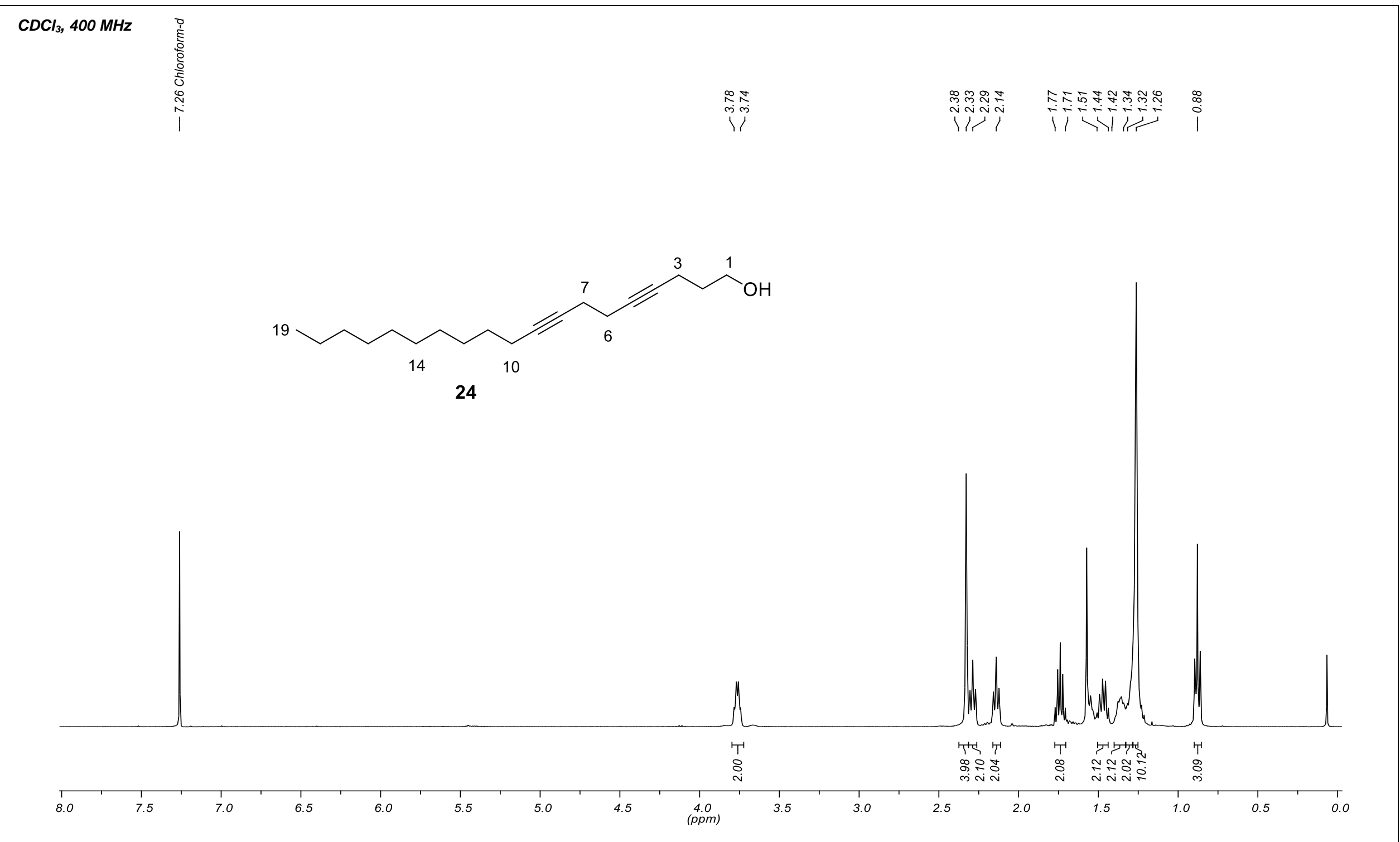




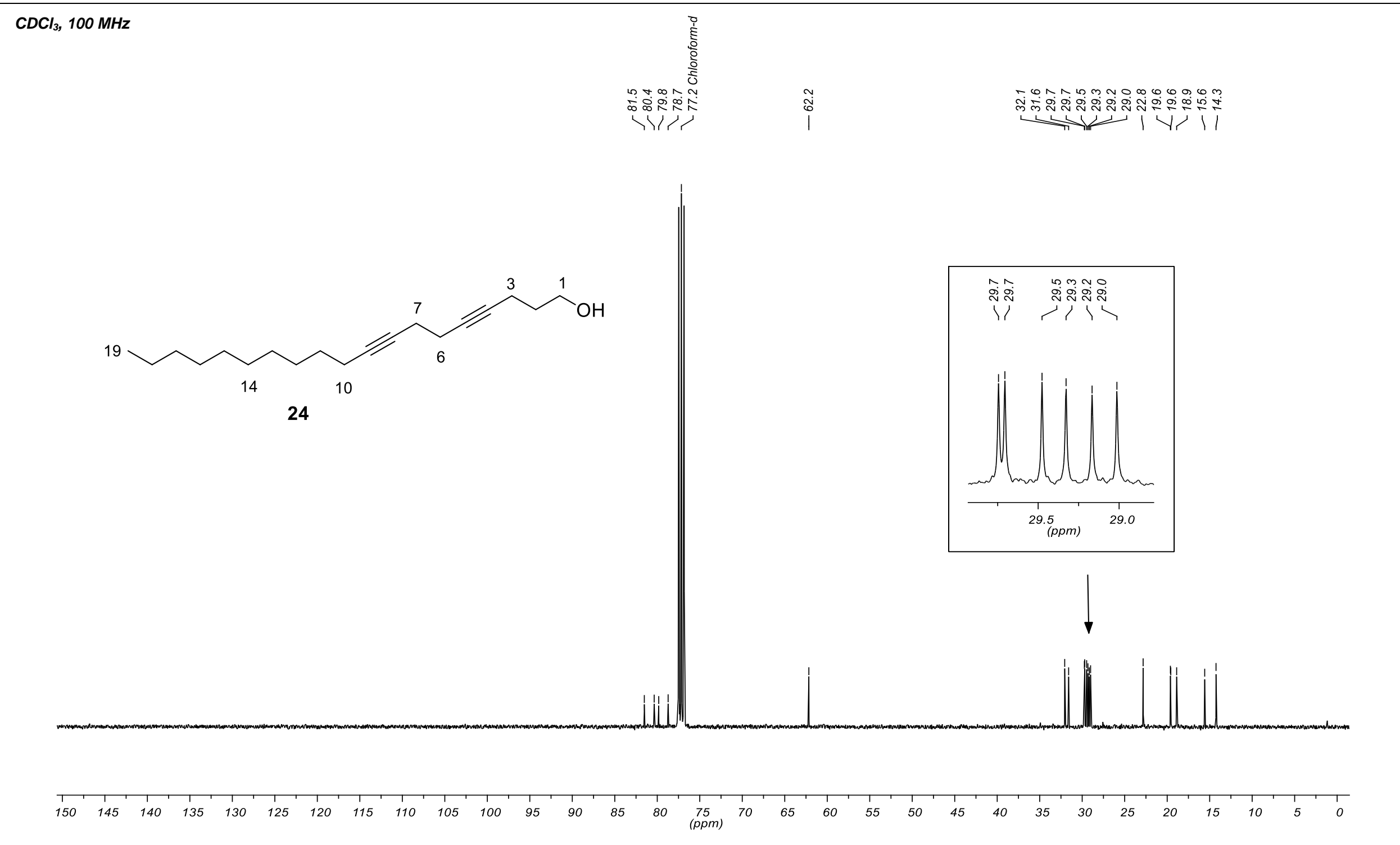




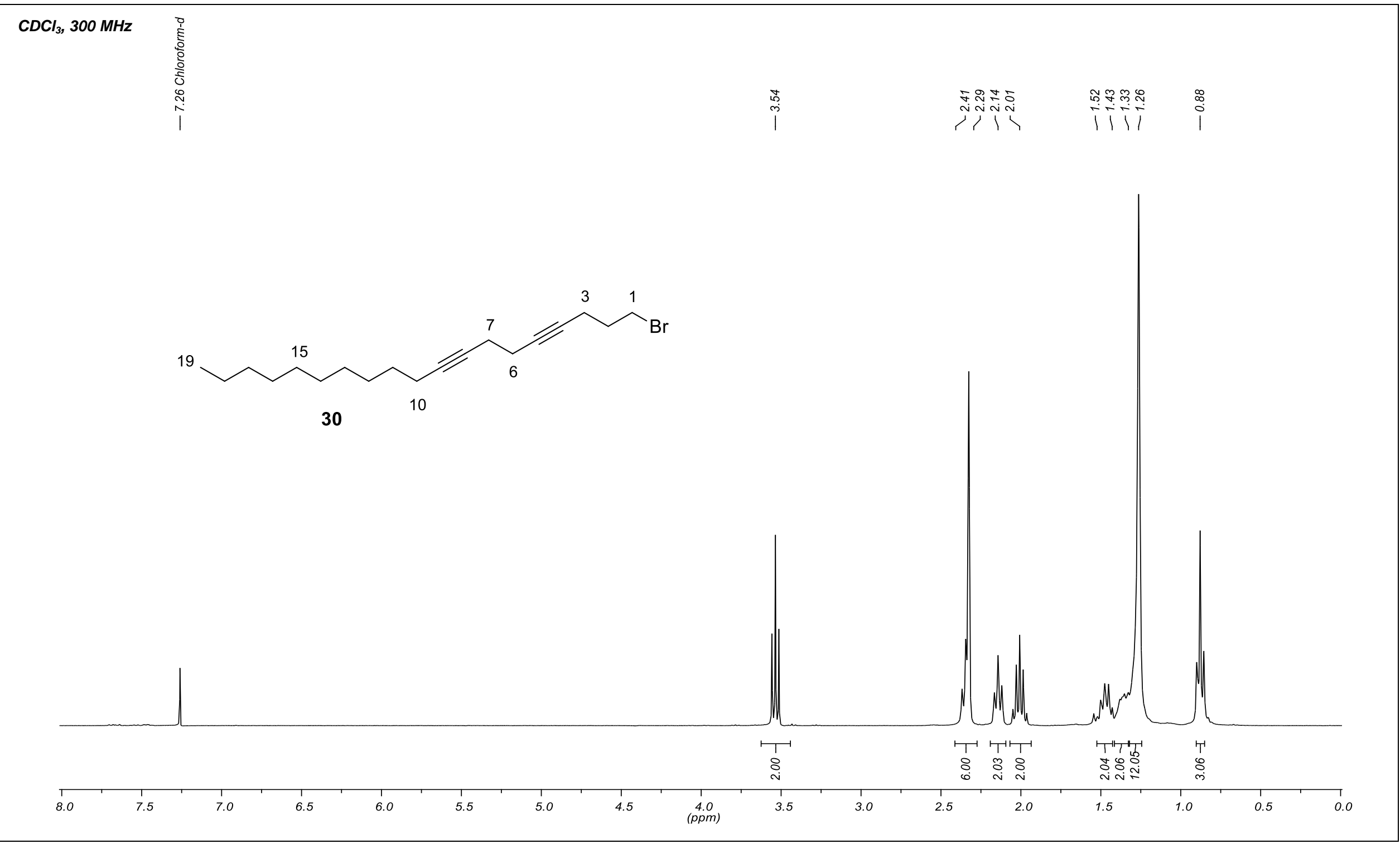




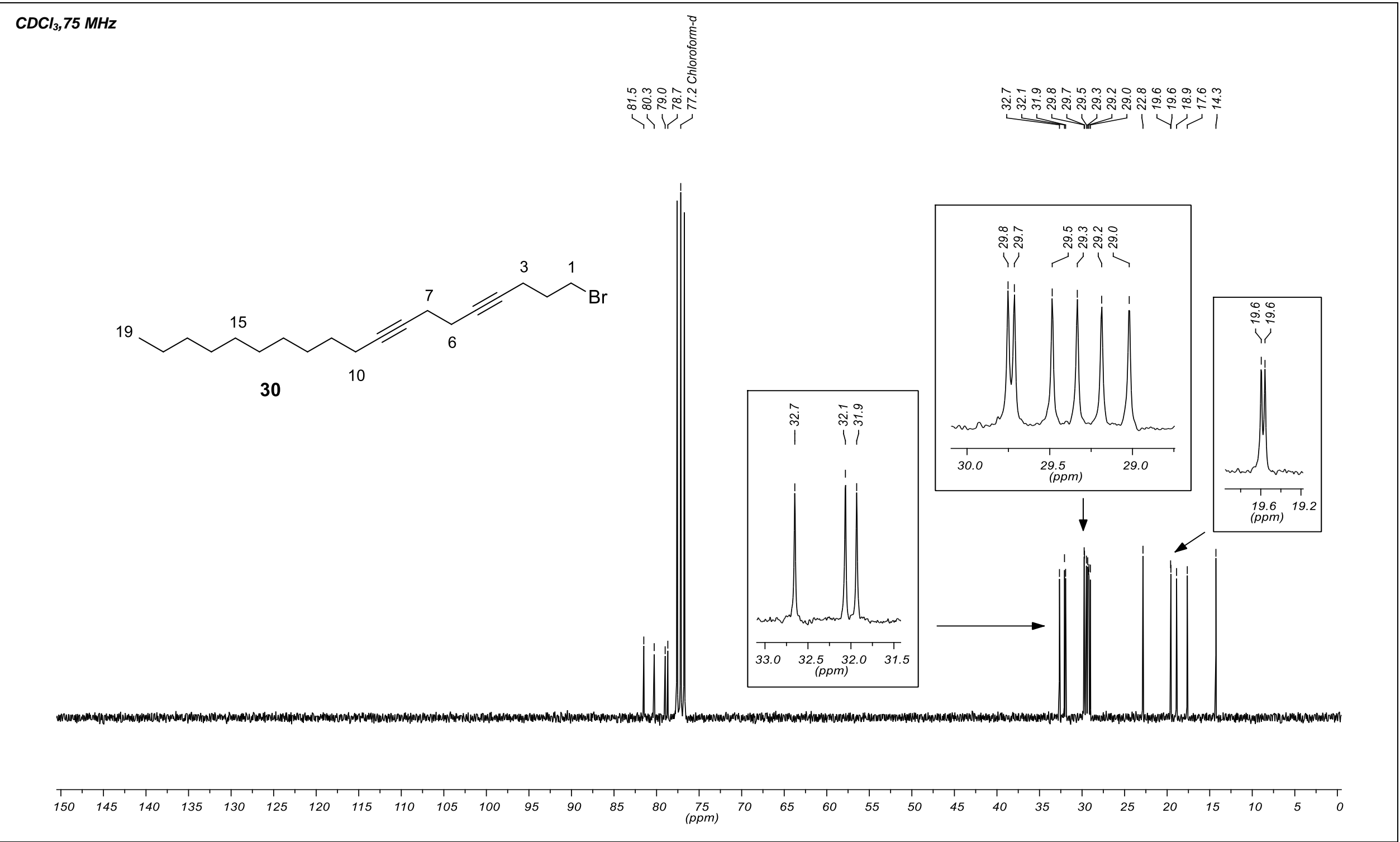




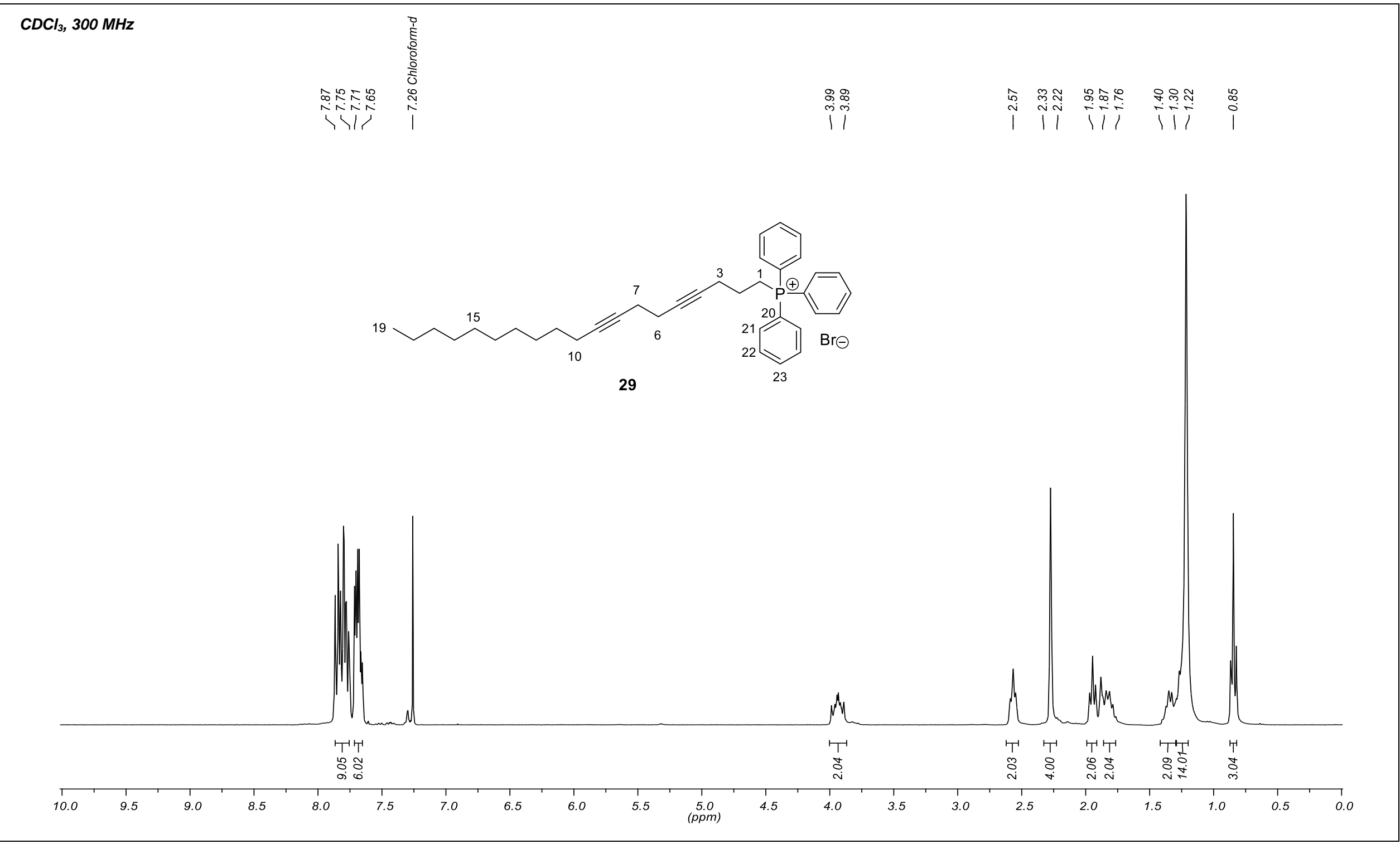




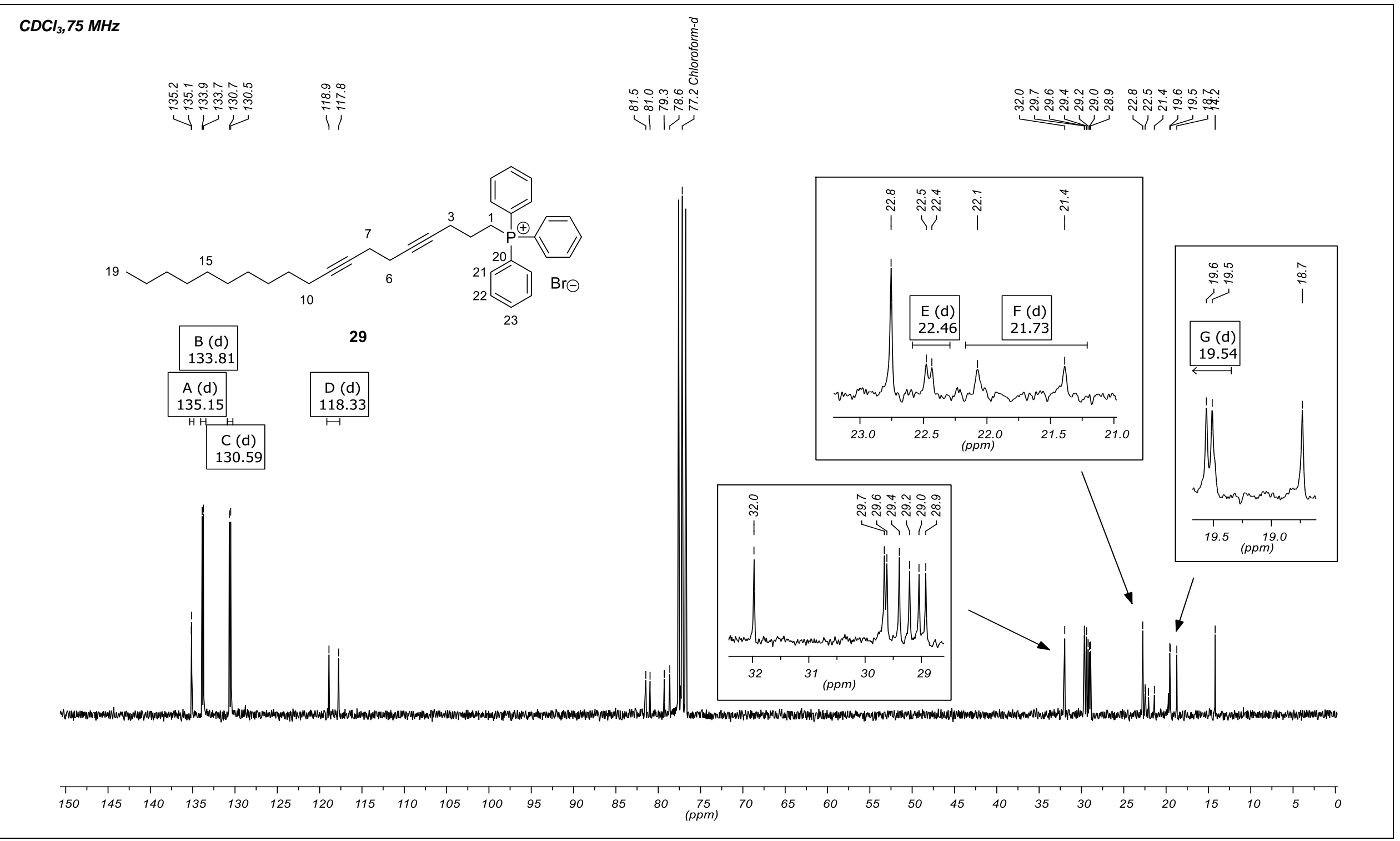




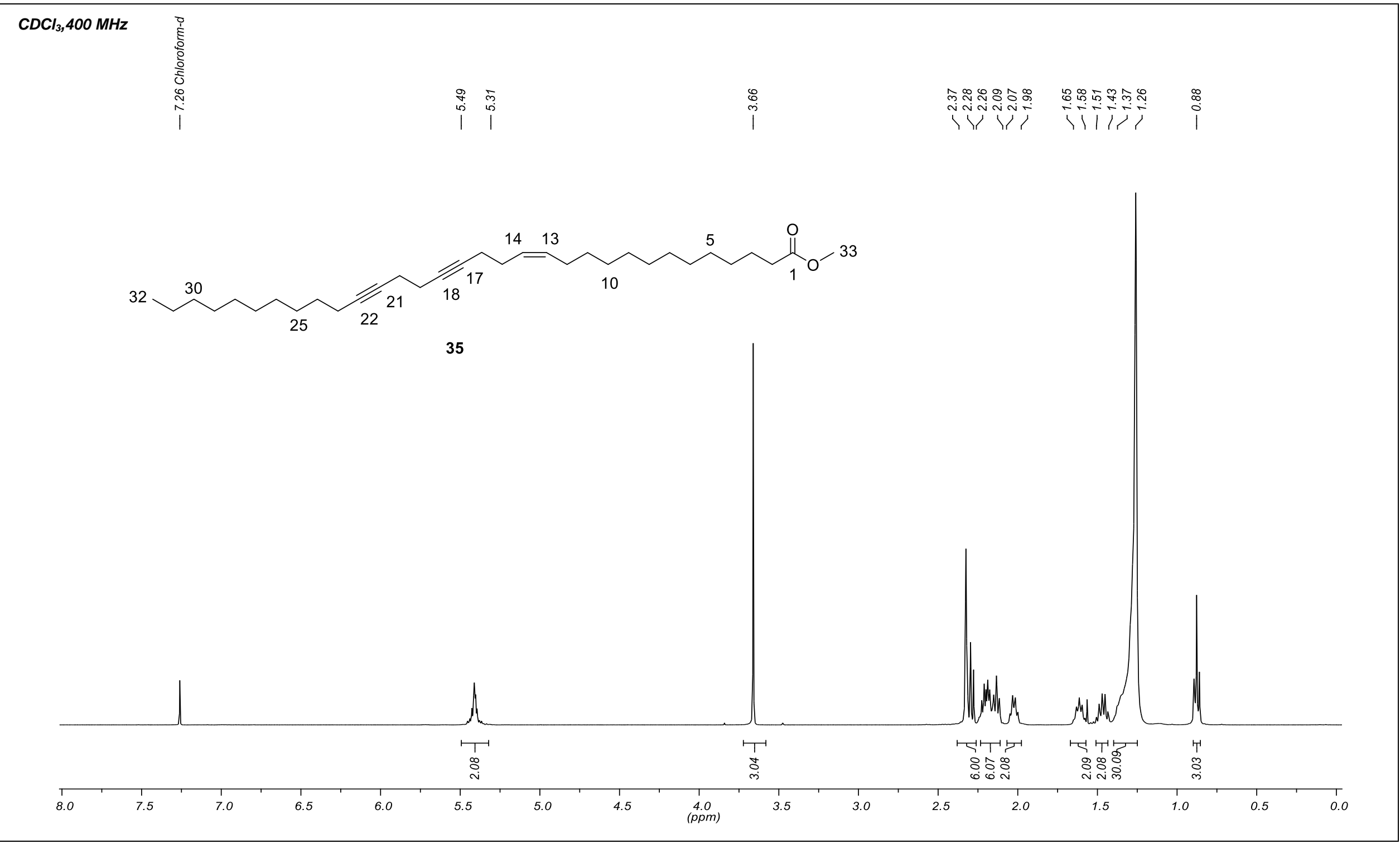




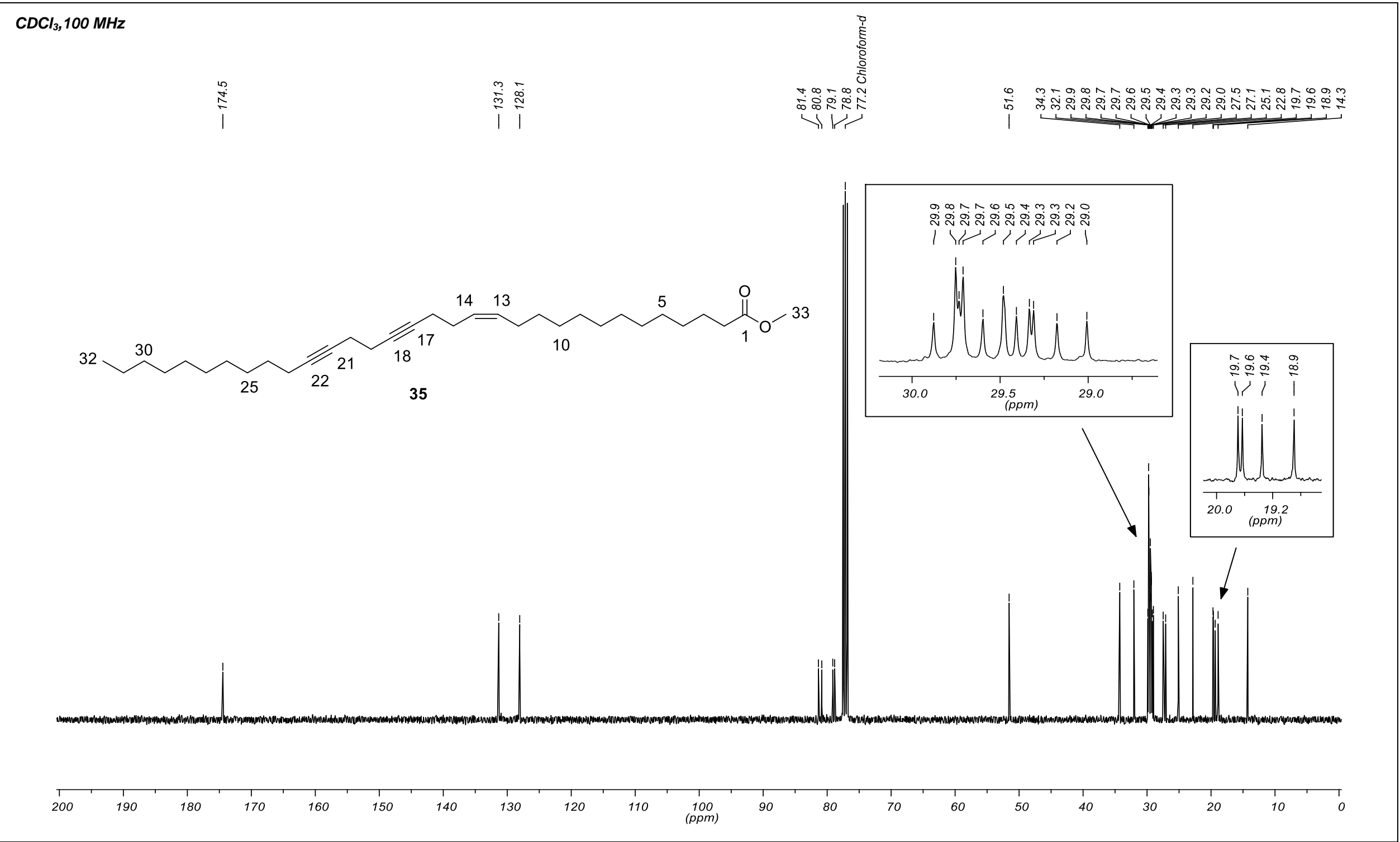




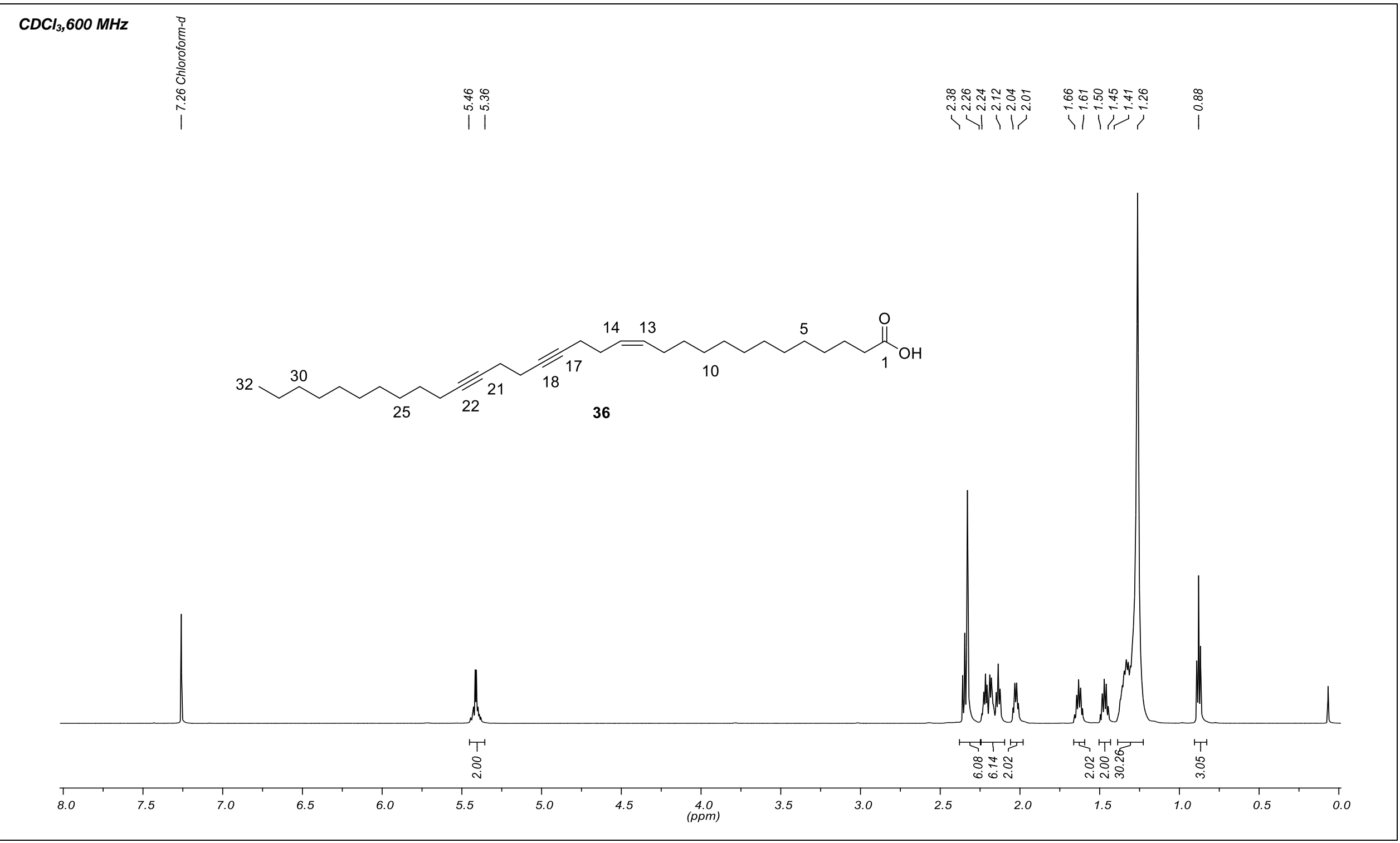




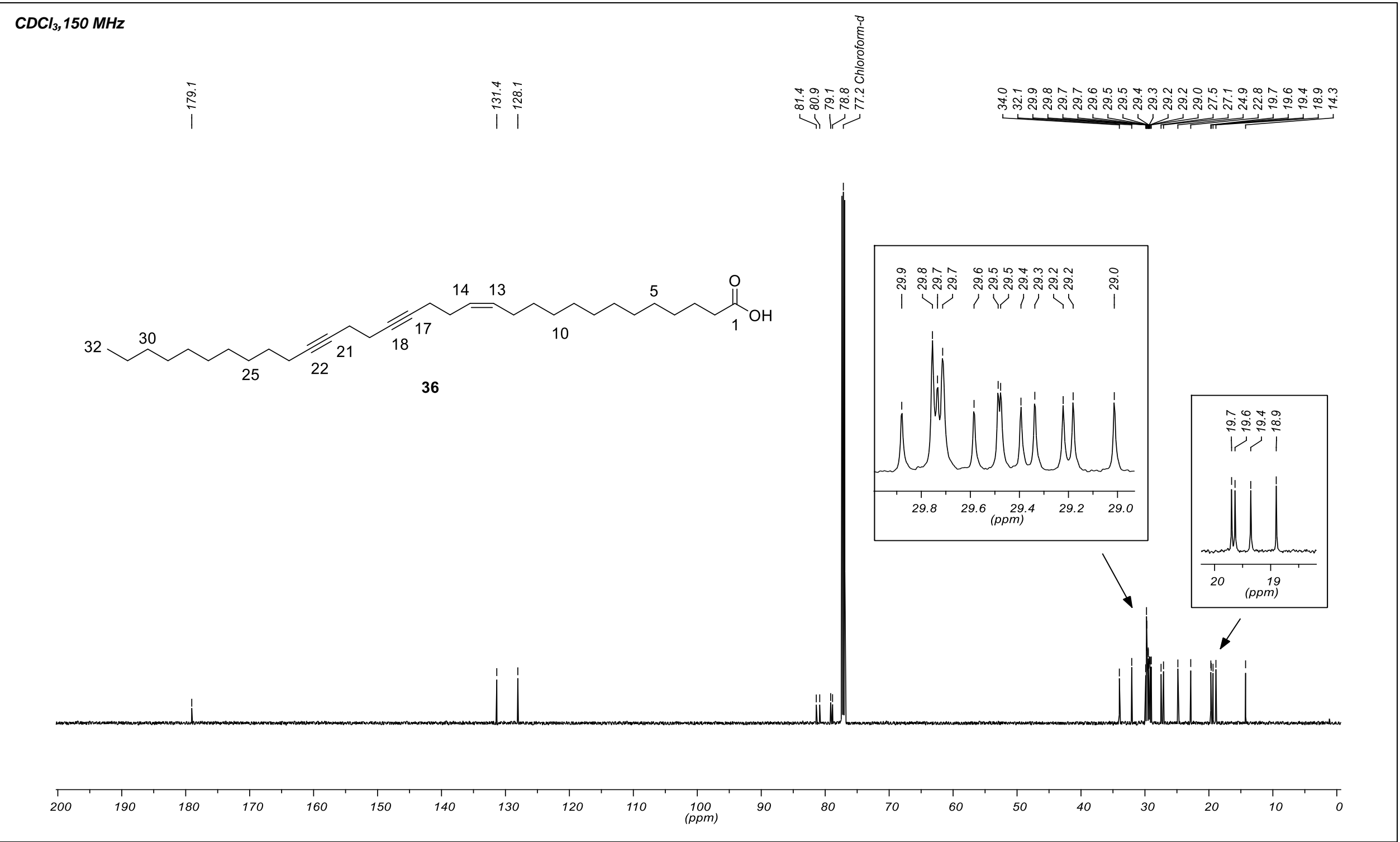




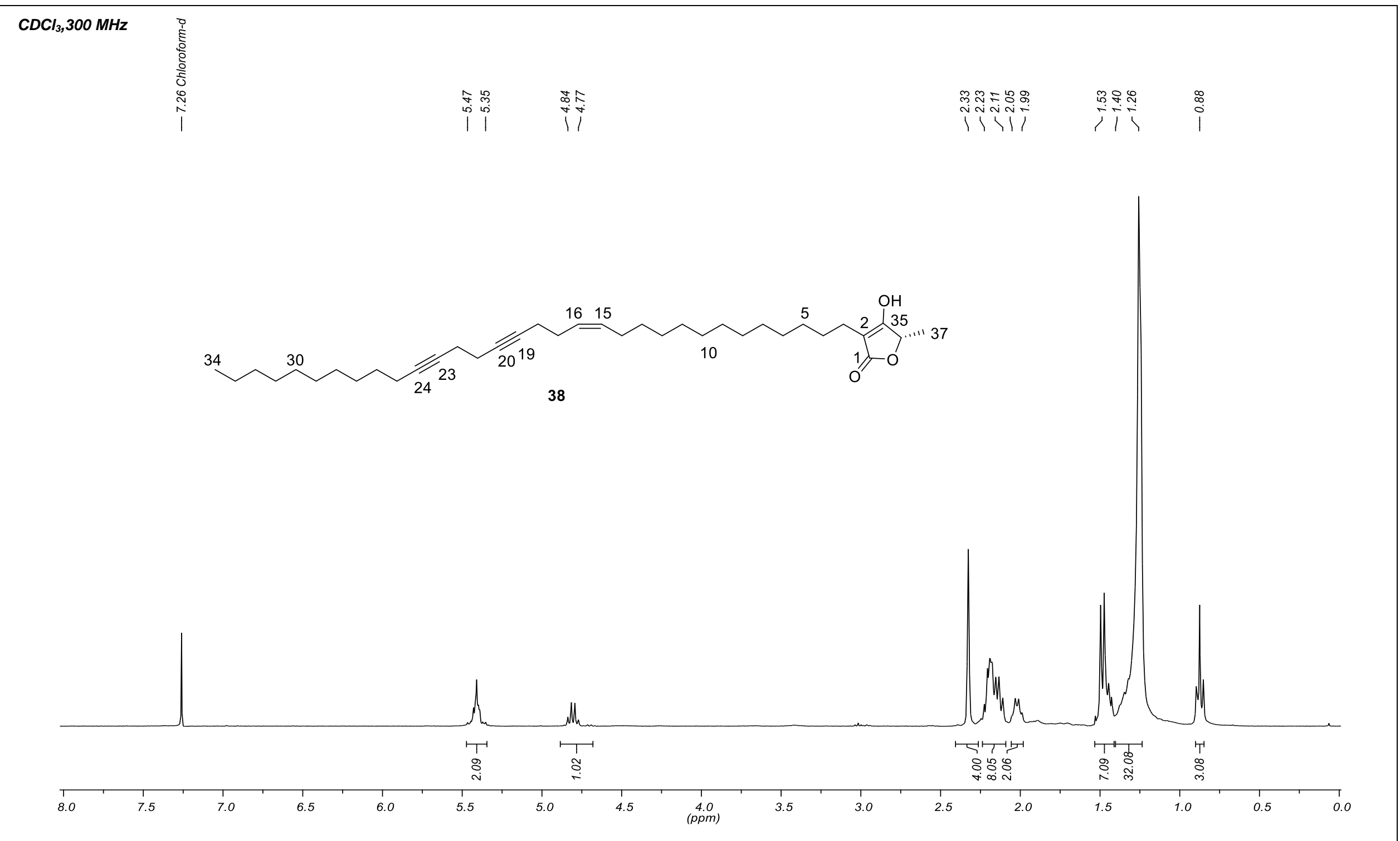




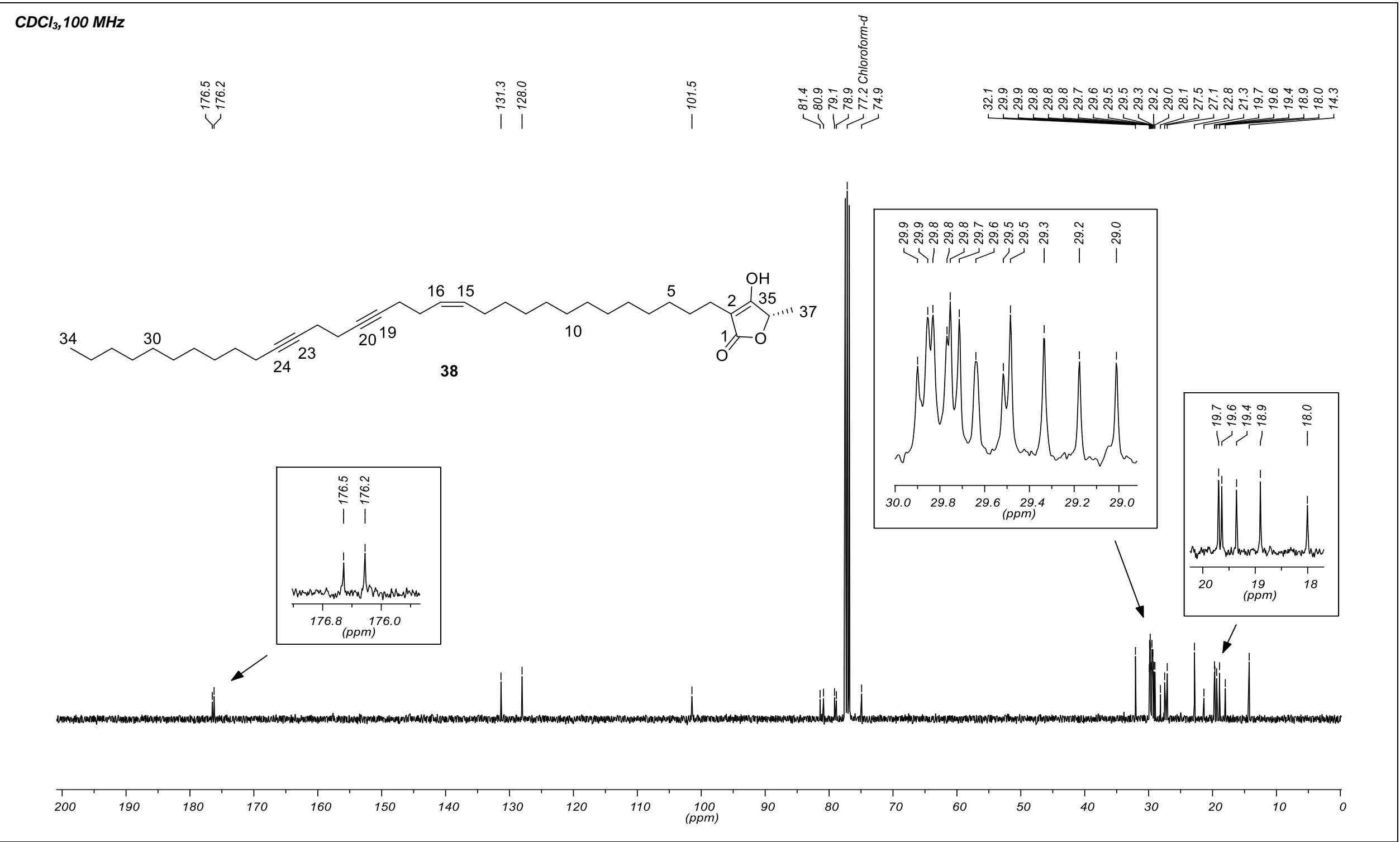




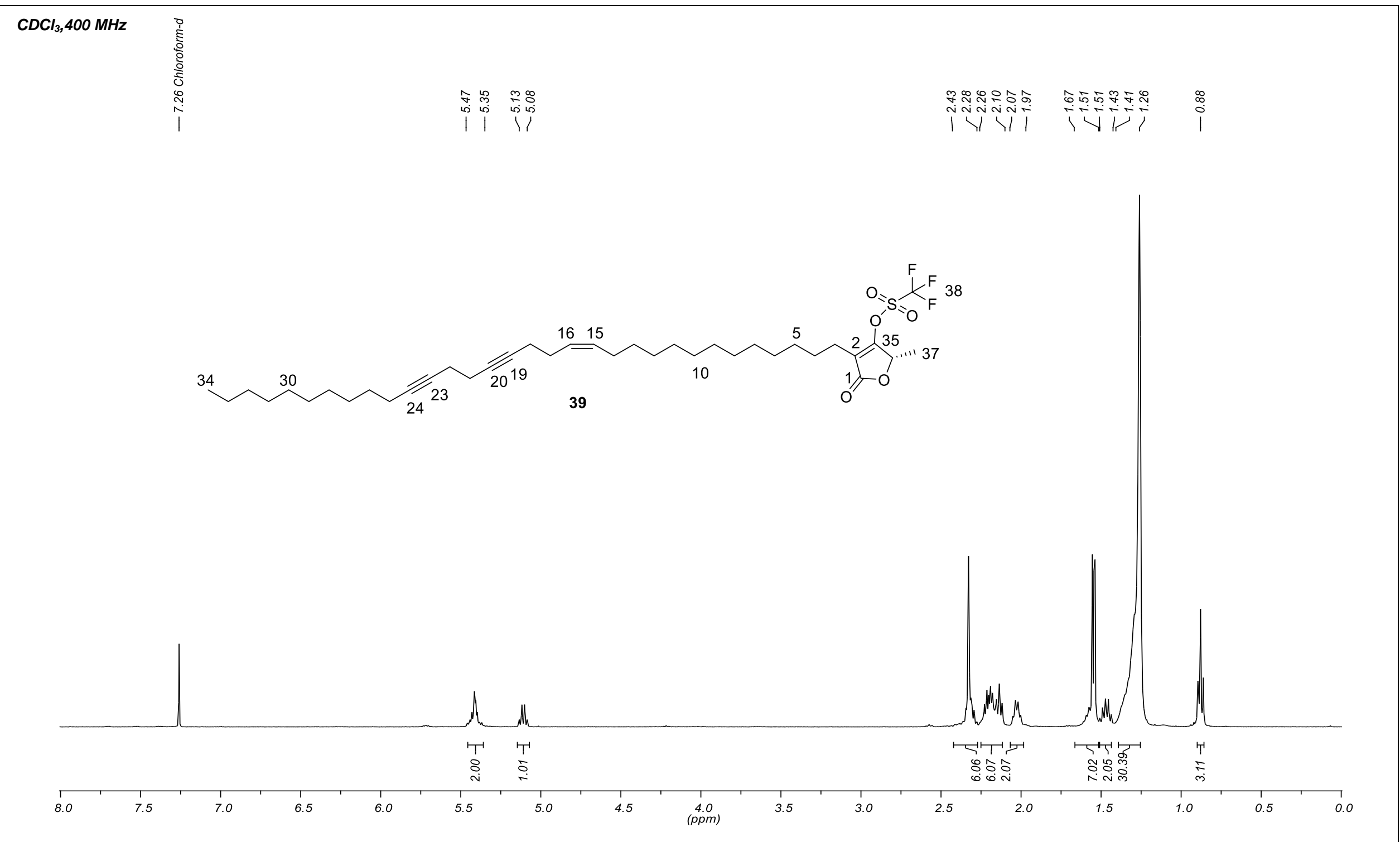




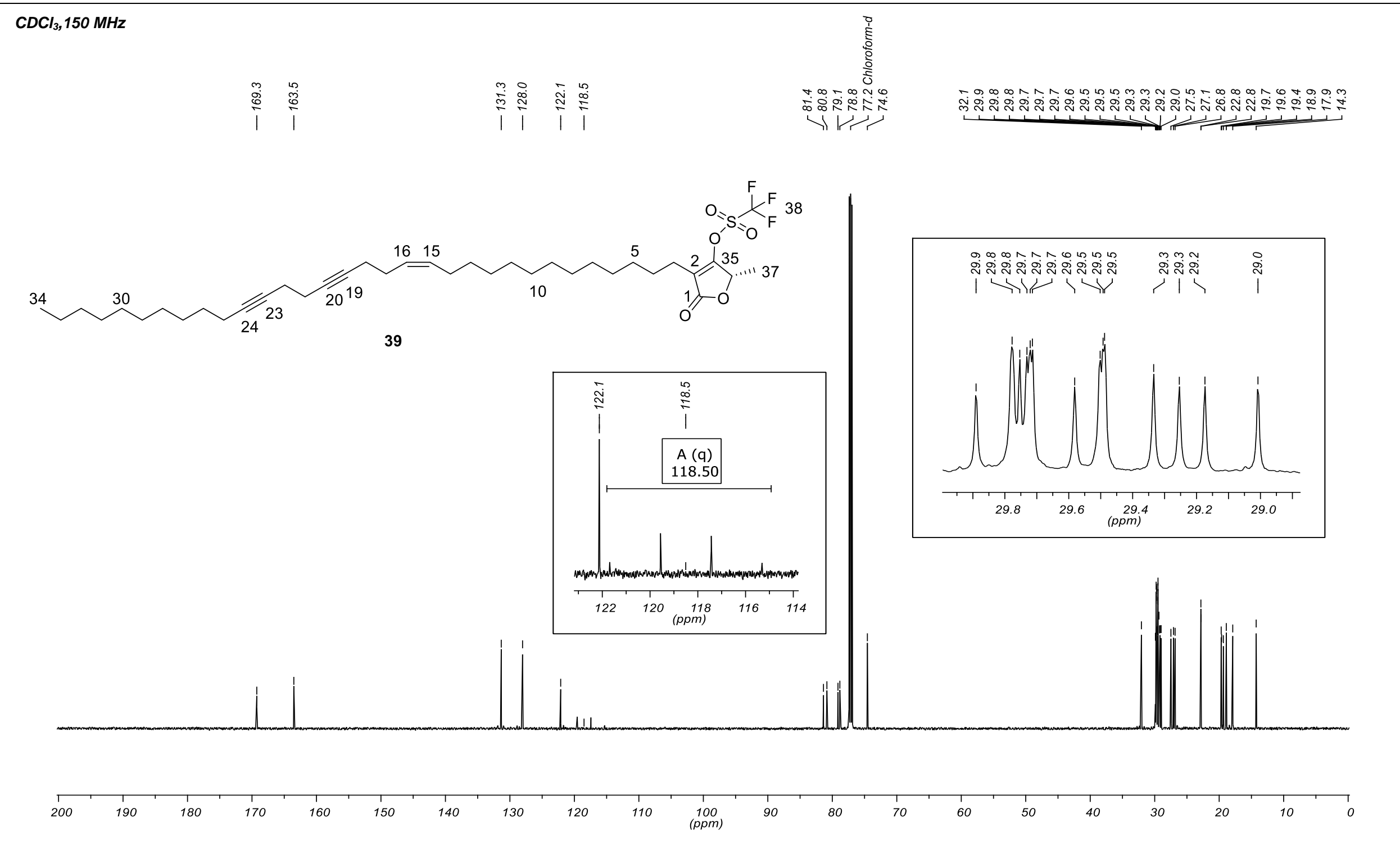



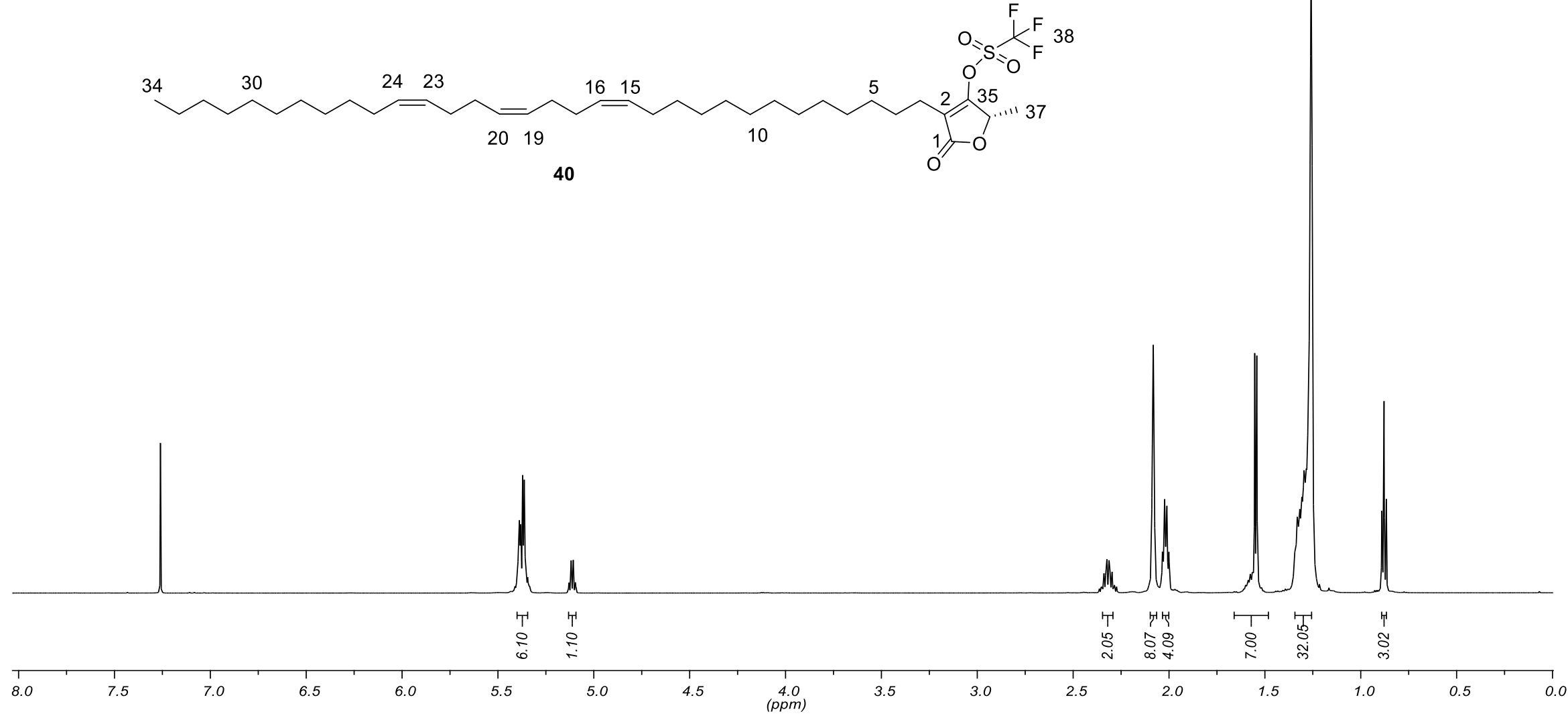


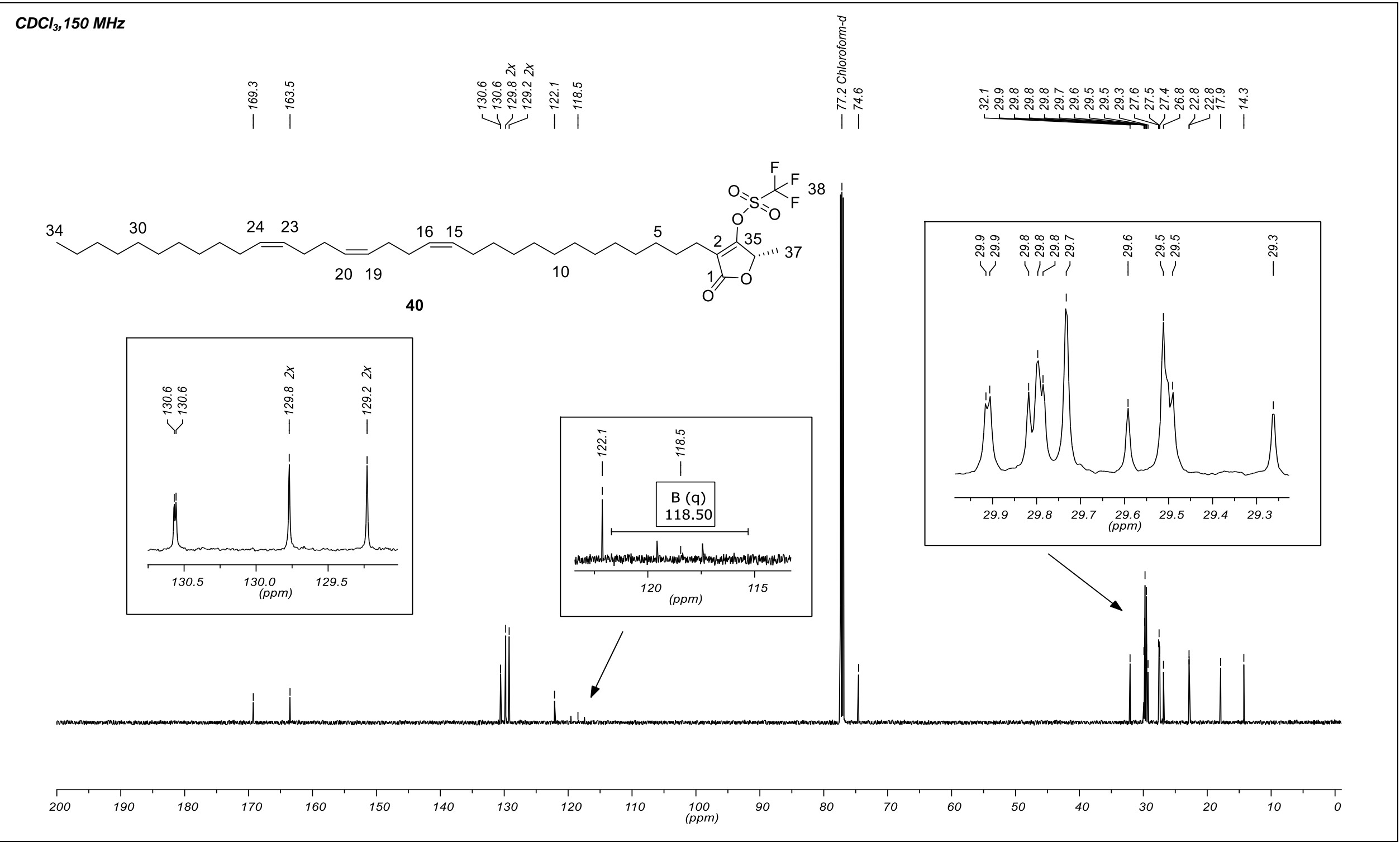




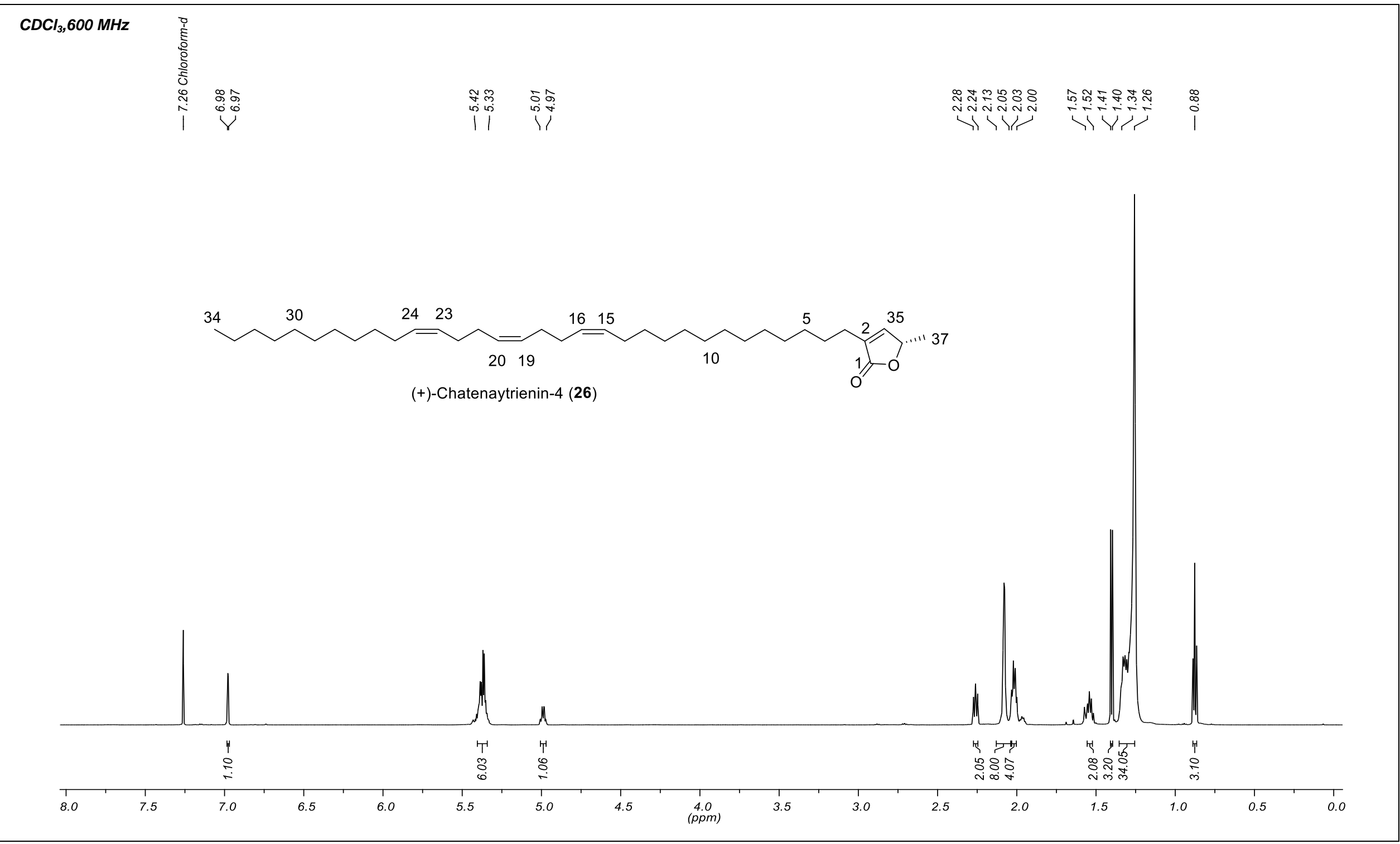




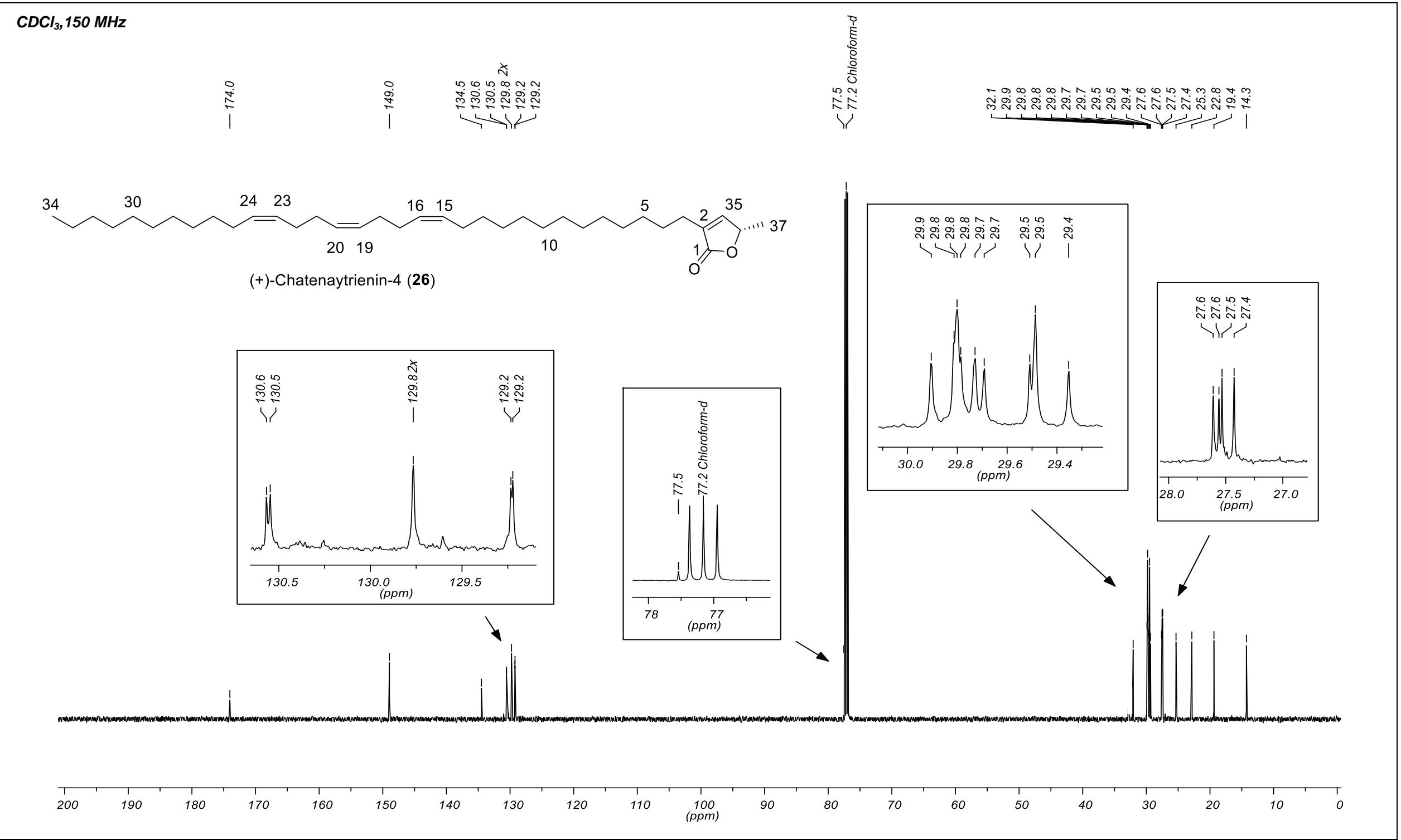

